\title{
Cannabinoids as therapeutic agents in cancer: current status and future implications
}

\author{
Bandana Chakravarti',*, Janani Ravi',**and Ramesh K. Ganju² \\ ${ }^{1}$ Molecular Medicine and Biotechnology Department, Sanjay Gandhi Post Graduate Institute of Medical Sciences, Lucknow, \\ India \\ 2 Department of Pathology, The Ohio State University, Columbus, Ohio, USA \\ * These authors contributed equally to this work \\ Correspondence to: Ramesh K. Ganju, email: Ramesh.ganju@osumc.edu \\ Keywords: Cannabinoid receptors, cannabinoid agonists, cancer, signaling \\ Received: May 19, $2014 \quad$ Accepted: July 17, $2014 \quad$ Published: July 17, 2014
}

This is an open-access article distributed under the terms of the Creative Commons Attribution License, which permits unrestricted use, distribution, and reproduction in any medium, provided the original author and source are credited.

\section{ABSTRACT}

The pharmacological importance of cannabinoids has been in study for several years. Cannabinoids comprise of (a) the active compounds of the Cannabis sativa plant, (b) endogenous as well as (c) synthetic cannabinoids. Though cannabinoids are clinically used for anti-palliative effects, recent studies open a promising possibility as anti-cancer agents. They have been shown to possess anti-proliferative and anti-angiogenic effects in vitro as well as in vivo in different cancer models. Cannabinoids regulate key cell signaling pathways that are involved in cell survival, invasion, angiogenesis, metastasis, etc. There is more focus on CB1 and CB2, the two cannabinoid receptors which are activated by most of the cannabinoids. In this review article, we will focus on a broad range of cannabinoids, their receptor dependent and receptor independent functional roles against various cancer types with respect to growth, metastasis, energy metabolism, immune environment, stemness and future perspectives in exploring new possible therapeutic opportunities.

\section{INTRODUCTION}

Cannabis sativa plant has been used for several hundreds of years both recreationally and medicinally. Centuries ago, the Chinese medicine refers to cannabis plant for pain-relief and hallucination. It contains 3 major classes of bioactive molecules; flavanoids, terpenoids and more than 60 types of cannabinoids [1]. Cannabinoids are the active compounds of this marijuana plant. But, the use of cannabinoids is in question because of their phsychotropic and addictive issues. The most active constituent of this plant is $\Delta^{9}$-tetrahydrocannabinol ( $\Delta^{9}$-THC), elucidated between 1940s and 1960s [2]. This discovery has opened the way to identification of the molecular action of various cannabinoids and the cannabinoid receptors. Evidence shows that smoking of cannabis preparations caused cancer of the respiratory and oral tracts or, at least, potentiated tobacco smokeinduced damages [3]. Cannabinoid is a family of complex chemicals (terpenophenolic compounds) that exert most of their actions by binding to and activating specific Gai protein-coupled receptors named as cannabinoid receptor, CB1 (Central receptor) and CB2 (Peripheral receptor) respectively [4-5]. $\mathrm{CB} 1$ and $\mathrm{CB} 2$ have been cloned and characterized from mammalian tissues, the main difference between them being their tissue expression pattern [6]. CB1 receptors are ubiquitously located, with their highest presence found in the central nervous system (basal ganglia, hippocampus, cerebellum and cortex) where they mediate cannabinoid psychoactive effects [7-8]. CB1 receptors are also present in peripheral nerve terminals, as well as in extra-neural tissues such as testis, uterus, vascular endothelium, eye, spleen, ileum and in adipocytes [8]. CB2 receptor expression is mostly restricted to particular elements of the immune system (enriched area of B lymphocyte) [9-10]. The human CB2 receptor shows $68 \%$ amino acid homology with the CB1 receptor in the trans-membrane domains and a $44 \%$ overall homology [9]. Cannabinoid receptors and their endogenous ligands termed as the endocannabinoid system have been used as putative molecular targets for the treatment of various diseases, including neurodegenerative diseases 
Table I: Cannabinoid's structure and its role in different physiological processes

\begin{tabular}{|c|c|c|}
\hline $\begin{array}{l}\text { Cannabinoid's name } \\
\text { (Abbreviation) and its target }\end{array}$ & Structure & Role \\
\hline Anandamide (AEA) CB1 agonist & & $\begin{array}{l}\text { Analgesic, antiemetic, appetite stimulant, tumour } \\
\text { growth inhibitor [159]. }\end{array}$ \\
\hline $\begin{array}{l}\text { 2-arachidonoyl-glycerol (2-AG) } \\
\text { CB1/CB2 agonist }\end{array}$ & & $\begin{array}{l}\text { Analgesic, antiemetic, appetite stimulant, tumour } \\
\text { growth inhibitor [159]. }\end{array}$ \\
\hline $\begin{array}{l}\text { Palmitoyl-ethanolamide (PEA) } \\
\text { CB2 agonist }\end{array}$ & & neuromodulatory and immunomodulatory [160]. \\
\hline $\begin{array}{l}\text { Docosatetraenyl ethanolamide } \\
\text { CB1 agonist }\end{array}$ & & neuromodulatory and immunomodulatory [160]. \\
\hline $\begin{array}{l}\text { Homo- } \gamma \text {-linoenylethanolamide } \\
\text { CB1 agonist }\end{array}$ & & neuromodulatory and immunomodulatory [160]. \\
\hline Oleamide CB1 agonist & & neuromodulatory and immunomodulatory [160]. \\
\hline $\begin{array}{l}\Delta^{9} \text {-tetrahydrocannabinol } \\
\text { THC }) \\
\text { CB1/CB2 agonist }\end{array}$ & & $\begin{array}{l}\text { Analgesic, antiemetic, appetite stimulant tumour } \\
\text { growth inhibitor [159]. }\end{array}$ \\
\hline $\begin{array}{l}\Delta^{8} \text {-tetrahydrocannabinol } \\
\left(\Delta^{8}-\mathrm{THC}\right) \mathrm{CB} 1 / \mathrm{CB} 2 \text { agonist }\end{array}$ & & $\begin{array}{l}\text { Anti-tumor agent, inhibitors of mitochondrial O2 } \\
\text { consumption in human sperm, antiemetic, appetite } \\
\text { stimulant }[151,161-163] \text {. }\end{array}$ \\
\hline cannabidiol (CBD), CB1 agonist & & 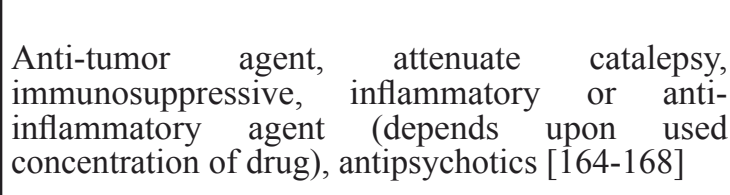 \\
\hline Cannabigerol (CBG), & & $\begin{array}{l}\text { multiple sclerosis, antiemetic, anti-inflammatory } \\
\text { agent, treatment for neurological disorder [169-171] }\end{array}$ \\
\hline Cannabichromene (CBC), & & $\begin{array}{l}\text { anti-inflammatory agent, treatment for neurological } \\
\text { disorder, hypomotility, antinociception, catalepsy, } \\
\text { and hypothermia [172-174] }\end{array}$ \\
\hline Tetrahydrocannabivarin (THCV), & & Hepatic ischaemia, anti-inflammatory [175-176] \\
\hline Cannabigerovarin (CBGV), & & Anti-inflammatory [177] \\
\hline
\end{tabular}




\begin{tabular}{|c|c|c|}
\hline $\begin{array}{l}\text { HU-210 } \\
\text { CB1/ CB2 Nonselective agonist }\end{array}$ & & Analgesic, multiple sclerosis, neuroprotective [159] \\
\hline $\begin{array}{l}\text { CP-55,940 } \\
\text { CB1/CB2 Nonselective agonist }\end{array}$ & & $\begin{array}{l}\text { Anti-cancer agent, Analgesic, antiemetic, appetite } \\
\text { stimulant }\end{array}$ \\
\hline $\begin{array}{l}R-(+)-W I N 55,212-2 \\
\text { CB1/ CB2 Nonselective agonist }\end{array}$ & ER & $\begin{array}{l}\text { Analgesic, antiemetic, appetite stimulant, tumour } \\
\text { growth inhibitor, } \\
\text { multiple sclerosis [159] }\end{array}$ \\
\hline $\begin{array}{l}\text { JWH- } 015 \\
\text { CB2 selective agonist }\end{array}$ & & Anti-tumor,anti-inflammatory, antiemetic [178] \\
\hline $\begin{array}{l}\text { JWH-133 } \\
\text { CB2 selective agonist }\end{array}$ & & Neurological disorders, Anti-cancer $[83,179]$ \\
\hline $\begin{array}{l}\text { JWH-139 } \\
\text { CB2 selective agonist }\end{array}$ & & $\begin{array}{l}\text { Analgesic, antiemetic, appetite stimulant tumour } \\
\text { growth inhibitor [159] }\end{array}$ \\
\hline $\begin{array}{l}\text { HU-308 } \\
\text { CB2 selective agonist }\end{array}$ & & $\begin{array}{l}\text { Tumour growth inhibitor (in glioma, skin carcinoma, } \\
\text { lymphoma [159] }\end{array}$ \\
\hline $\begin{array}{l}\text { CP55940 } \\
\text { CB/CB2 agonist }\end{array}$ & & $\begin{array}{l}\text { Analgesic, antiemetic, appetite stimulant, tumour } \\
\text { growth inhibitor, } \\
\text { multiple sclerosis [159] }\end{array}$ \\
\hline $\begin{array}{l}R \text {-(+)-methanandamide } \\
\text { CB1 agonist }\end{array}$ & & $\begin{array}{l}\text { Analgesic, antiemetic, appetite stimulant tumour } \\
\text { growth inhibitor [159] }\end{array}$ \\
\hline AM251 CB1 antagonist & & Metabolic syndrome [180] \\
\hline AM281 CB1 antagonist & & $\begin{array}{l}\text { Improves recognition loss induced by naloxone in } \\
\text { morphine withdrawal mice, various pharmacological } \\
\text { property [181-182] }\end{array}$ \\
\hline
\end{tabular}

(Alzheimer's disease, Parkinson's disease, Huntington's disease, etc.), neuropathic and inflammatory pain, glaucoma, multiple sclerosis, cardiovascular disorders and obesity etc [5].

Recently cannabinoid's role has been explored in the area of cancer research. Cancer is caused by uncontrolled proliferation of cells and the ability of these cells to invade into other tissues and spread. Anti-cancer agents function as apoptotic, cell cycle defective or DNA damage agents. A major discovery in cancer in cannabinoid use in cancer treatment is its ability in targeted killing of tumors. Several preclinical studies suggest that $\Delta^{9}$-THC, other naturally occurring cannabinoids, synthetic cannabinoid agonists and endocannabinoids have anti-cancer effects in vitro 
against lung carcinoma, gliomas, thyroid epithelioma, lymphoma, skin carcinoma, uterine carcinoma, breast cancer, prostate carcinoma, pancreatic cancer and neuroblastoma [4]. These findings were also supported by in vivo studies and the majority of effects of cannabinoids are mediated via $\mathrm{CB} 1$ and $\mathrm{CB} 2$. The transient receptor potential vanilloid type 1 (TRPV1) has been described as an additional receptor target for several cannabinoids. In addition, the palliative effects of cannabinoids include inhibition of nausea and emesis which are associated with chemo- or radiotherapy, appetite stimulation, pain relief, mood elevation and relief from insomnia in cancer patients. Synthetic THC (Marinol, Dronabinol) and its derivative nabilone (Cesamet), as well as Sativex, have been approved in several countries to control nausea and cancer-related pain in cancer patients undergoing chemotherapy [11-12]. In this review article we focused on the role of cannabionds in different cancer types and the respective signaling pathways.

\section{Cannabinoid and its receptor}

Cannabinoids can be classified into three groups based on their source of production; endogenous cannabinoids (endocannabinoids), phytocannabinoids and synthetic cannabinoids (Fig.1) and their putative molecular targets (CB1 or CB2 receptor or TRPV1) have been identified (Table I). The central and most of the peripheral effects of cannabinoids rely on CB1 receptor activation.

\section{Endogenous cannabinoids}

Endogenous cannabinoids which are produced in our body include lipid molecules containing long-chain polyunsaturated fatty acids, amides, esters and ethers that bind to $\mathrm{CB} 1$ or $\mathrm{CB} 2$ receptors. Several pharmacological evidences show that endocannabinoids also exert biological effects through non-CB1/CB2 receptors [13]. Endocannabinoids mainly act as neuromodulators or retrograde messengers which affect the release of various neurotransmitters in the peripheral and neural tissues [14]. They also play important role in inflammation, insulin sensitivity, and fat and energy metabolism. Inhibition of endocannabinoids may be a tool in reducing the prevalence of metabolic syndrome [15]. Two of the best characterized endocannabinoids are $\mathrm{N}$-arachidonoylethanolamine (AEA-anandamide) and 2- arachidonoylglycerol (2AG) which affect our mood, appetite, pain sensation, inflammation response, and memory [7, 16]. Anandamide which was isolated from porcine brain in 1992 was shown as the first brain metabolite, to function as a ligand for CB1, [7]. 2-arachidonoyl-glycerol which was isolated from canine gut acts through both $\mathrm{CB} 1$ and $\mathrm{CB} 2$ receptors [16-17]. Palmitoyl-ethanolamide, or N-(2-Hydroxyethyl) hexadecamide ( $\mathrm{N}$-acyl-ethanolamide) is co-synthesized with anandamide in all tissues and acts through CB2 [18-20]. Other unsaturated fatty acid ethanolamides like Docosatetraenylethanolamide and Homo- $\gamma$ linoenylethanolamide act as agonists for the neuronal CB1 receptor [20-21]. Another putative endogenous cannabinoid, oleamide, or cis-9-octadecenoamide, has also been isolated and shown to have similar actions to anandamide in the behavioral rodent tests [22].

\section{Phytocannabinoids}

Phytocannabinoids are only known to occur naturally in significant quantity in the cannabis plant, and are concentrated in a viscous resin that is produced in glandular structures known as trichomes. $\Delta^{9}$-THC, cannabidiol (CBD) and cannabinol $(\mathrm{CBN})$ are the

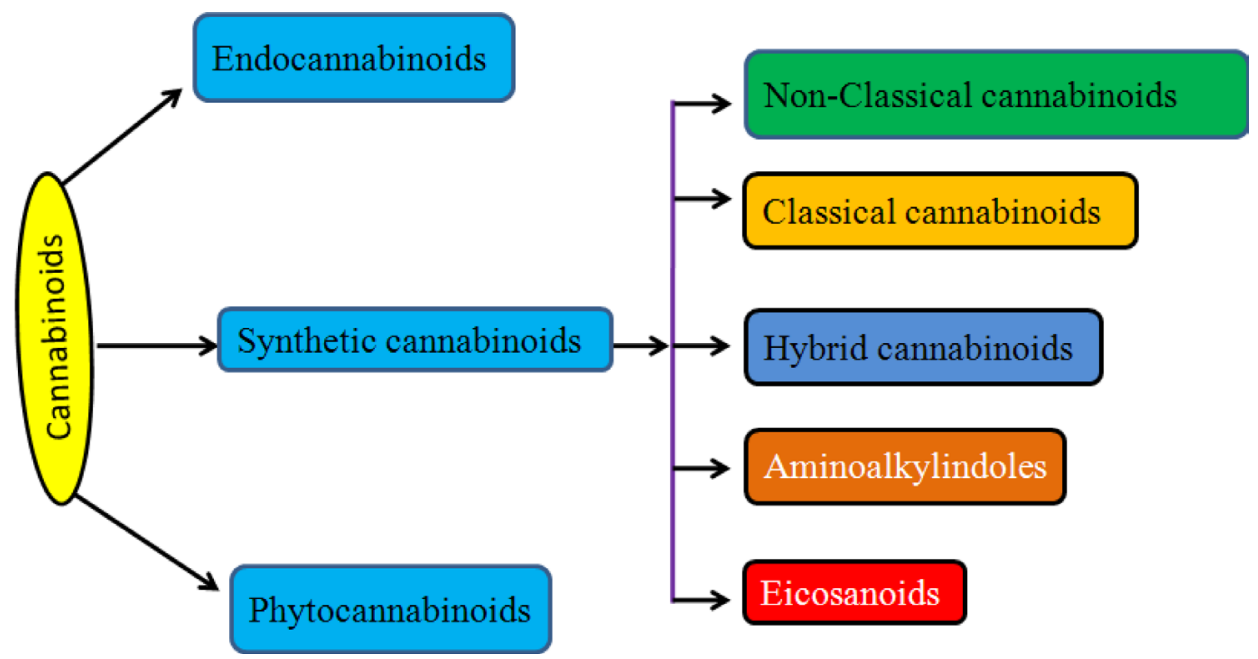

Fig.1: Cannabinoids and their classification. This figure illustrates how cannabinoids are divided into three main categories according to their availability in nature. 
Table II: Role of cannabinoid in different cancers and its associated signaling

\begin{tabular}{|c|c|}
\hline Cannabinoids & Anti-cancer effect and its mechanism of action \\
\hline Anandamide & $\begin{array}{l}\text { 1)Breast cancer: (blocks G1 - S phase transition)-Regulates Raf- 1/ERK/MAP pathway, } \\
\text { Wnt/ } \beta \text { catenin signaling } \\
\text { 2)Prostate cancer: Regulates EGFR pathway }\end{array}$ \\
\hline $\mathrm{THC}$ & 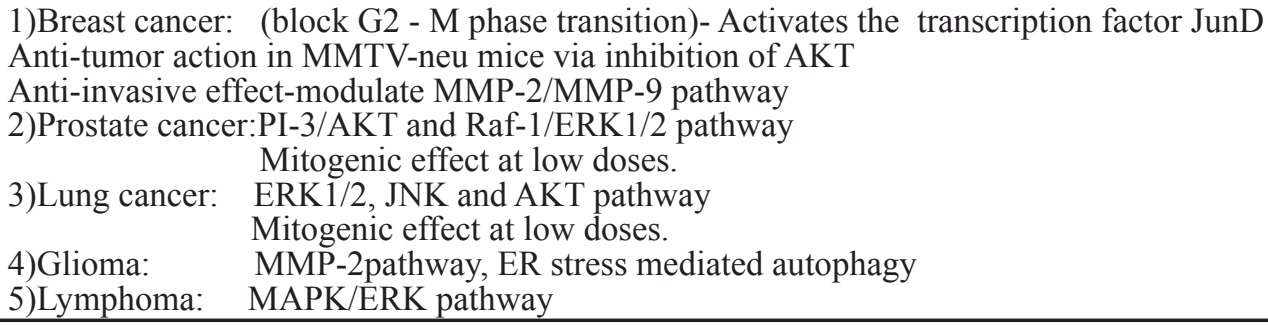 \\
\hline $2-\mathrm{AG}$ & $\begin{array}{l}\text { 1)Breast cancer: Suppression of nerve growth factor Trk receptors and prolactin receptors } \\
\text { Prostate cancer: NF- } \mathrm{B} / \text { cyclin } \mathrm{D} \text { and cyclin E, Suppression of nerve growth factor Trk } \\
\text { receptors and prolactin receptors. } \\
\text { 2)Glioma: Inhibition } \mathrm{Ca}(2+) \text { influx } \\
\text { 3)Bone cancer: Attenuates mechanical hyperalgesia }\end{array}$ \\
\hline HU120 & 1)Prostate cancer: AKT pathway \\
\hline WIN-55,212-2 & $\begin{array}{ll}\text { 1)Breast cancer: } & \text { Regulates COX-2/PGE2 signaling pathway } \\
\text { 2)Prostate cancer: Sustained activation of ERK1/2 } \\
\text { 3)Skin cancer: } \quad \text { Inhibits pro-angiogenic growth factor, AKT and pRB pathway } \\
\text { 4)Glioma: } \quad \text { Ceramide and NF-Kb pathway } \\
\text { 5)Lymphoma: } \quad \text { Ceramide and p } 38 \text { pathway }\end{array}$ \\
\hline $\mathrm{R}-(+)-\mathrm{MET}$ & $\begin{array}{l}\text { 1)Breast cancer: decreased phosphorylation of focal adhesion-associated protein kinase } \\
\text { and Src and tyrosine kinases involved in migration and adhesion } \\
\text { 2)Prostate cancer: mitogenic effect at low dose }\end{array}$ \\
\hline JWH-133 & $\begin{array}{l}\text { 1)Breast cancer: inhibition of AKT-Regulate COX-2/PGE2 signaling pathway } \\
\text { 2)Lung cancer: MMPs pathway } \\
\text { 3)Skin cancer: G1 arrest-AKT pathway }\end{array}$ \\
\hline Met-F-AEA & $\begin{array}{l}\text { 1)Breast cancer: S phase cell cycle arrest } \\
\text { Regulates FAK/Src and RhoA-ROCK pathways }\end{array}$ \\
\hline JWH-015 & $\begin{array}{l}\text { 1)Breast cancer: CXCR-4/CXCL12 pathway } \\
\text { 2)Prostate cancer: JNK/AKT signaling pathway }\end{array}$ \\
\hline$\Delta^{9}-\mathrm{THC}$ & $\begin{array}{ll}\text { 1)Breast cancer: } & \text { mitogenic effect in cells expressing low levels of CB1/CB2 receptors. } \\
\text { 2)Prostate cancer: PI3K/Akt and Raf-1/ERK1/2 pathway } & \text { Mitogenic at low doses } \\
& \text { EGFR/ERK1/2, c-Jun-NH2-kinase1/2, and Akt pathway. } \\
\text { 3)Lung cancer: } & \text { Mitogenic at low doses } \\
& \text { MMP-2 pathway } \\
\text { 4)Glioma: } & \text { MMand }\end{array}$ \\
\hline CBD & $\begin{array}{l}\text { 1)Breast cancer: ER stress/ERK and reactive oxygen species (ROS) pathways } \\
\text { 2)Prostate cancer: ERK } 1 / 2 \text { and AKT pathways } \\
\text { 3)Lung cancer: } \quad \text { up-regulation of TIMP-1 } \\
\quad \text { Cox-2 and PPAR- } \gamma \text { regulation } \\
\text { 4)Cervical cancer: Up-regulation of TIMP1 }\end{array}$ \\
\hline CBDA & 1)Breast cancer: PKA/RhoA pathway \\
\hline AME1241 & 1)Bone cancer: Anti-nociception \\
\hline
\end{tabular}

most prevalent natural cannabinoids [23]. $\Delta^{9}$-THC binds with similar affinities for both $\mathrm{CB} 1$ and $\mathrm{CB} 2$ receptors at submicromolar concentration. It behaves as a $\mathrm{CB} 1$ receptor partial agonist and $\mathrm{CB} 1 / \mathrm{CB} 2$ receptor antagonist [24]. $\Delta^{8}$-THC has similar affinities for CB1 and $\mathrm{CB} 2$ receptors as like $\Delta^{9}$-THC [25]. Other common cannabinoids are cannabidiol (CBD), Cannabigerol (CBG), Cannabichromene (CBC), Cannabicyclol (CBL), Cannabivarin (CBV), Tetrahydrocannabivarin (THCV), Cannabidivarin (CBDV), Cannabichromevarin (CBCV),
Cannabigerovarin (CBGV), Cannabigerol Monoethyl Ether (CBGM).

\section{Synthetic cannabinoids}

Synthetic cannabinoids have been extensively used as a pharmacological agent, both in vitro and in vivo, to obtain more detailed insight of cannabinoid action, in order to evaluate their potential clinical use. They showed both antineoplastic and protumoral activity, depending 
on type of agonist, target tissues, route of administration, doses and duration of the treatment [26-27]. Synthetic cannabinoids are classified on the basis of chemical structure of molecules and they are capable of a more selective activation of cannabinoid receptor [28].

\section{a) Classical cannabinoids}

Compounds isolated from the plant C. sativa or synthetic analogs of these compounds fall into this category. HU-210, $\Delta^{9}$-THC, $\Delta^{8}$-THC and desacetyl-Lnantradol are synthetic cannabinoids which behave as $\mathrm{CB} 1 / \mathrm{CB} 2$ receptor agonists (lack of $\mathrm{CB} 1 / \mathrm{CB} 2$ selectivity. The most psychotropic component of the C.sativa plant is $\Delta^{9}$-THC which shows affinity for both the cannabinoid receptors. Increased affinity of HU-210 is due to replacing pentyl side chain of $\Delta^{8}$-THC with a dimethylheptyl group. Other CB2-selective agonists that have been synthesized by structurally modifying THC molecule are JWH-133, JWH-139, and HU-308 and L-759633 and L-759656 which was effective in nanomolar range [29-31].

\section{b) Nonclassical Cannabinoids}

These are a family of AC-bicyclic and ACDtricyclic cannabinoid analogs. Furthermore bi-cyclic analog, CP55940, an important cannabinoid agonist has similar affinity for $\mathrm{CB} 1$ and $\mathrm{CB} 2$ receptors. Also, it is highly potent in vivo. CP55244 and CP47497 are other cannabinoids that fall in this category.

\section{c) Aminoalkylindoles}

These are a family of aminoalkylindoles with cannabimimetic properties. R-(+)-WIN55212 is the most well known compound in this series. It exhibits high affinity for both cannabinoid receptors, but more selective for $\mathrm{CB} 2$. It has similar pharmacological effects like THC in vivo. JWH-015 and L-768242 also show affinity towards CB2 than R-(+)-WIN55212 [32].

\section{d) Eicosanoids}

Anandamide, which is an endogenous cannabinoid ligand was originally discovered in mammalian brain and other tissues and acts similar to THC. Methanandamide, its $\mathrm{R}-(+)$-isomer is nine times more CB1 specific than the $\mathrm{S}$-(+)-isomer [33]. 2-arachidonoylglycerol, another well studied endocannabinoid has both CB1 and CB2 affinities. Other compounds are arachidonyl-2-chloroethylamide (ACEA) and arachidonylcyclopropylamide (ACPA).

\section{e) Others}

These represent diarylpyrazole compounds which function antagonistic to cannabinoid receptors [34]. SR141716A is a potent CB1 antagonist and SR144528 is a CB2 antagonist [35-36]. AM251 and AM281 are analogs of SR141716A which block CB1 receptor-mediated effects.

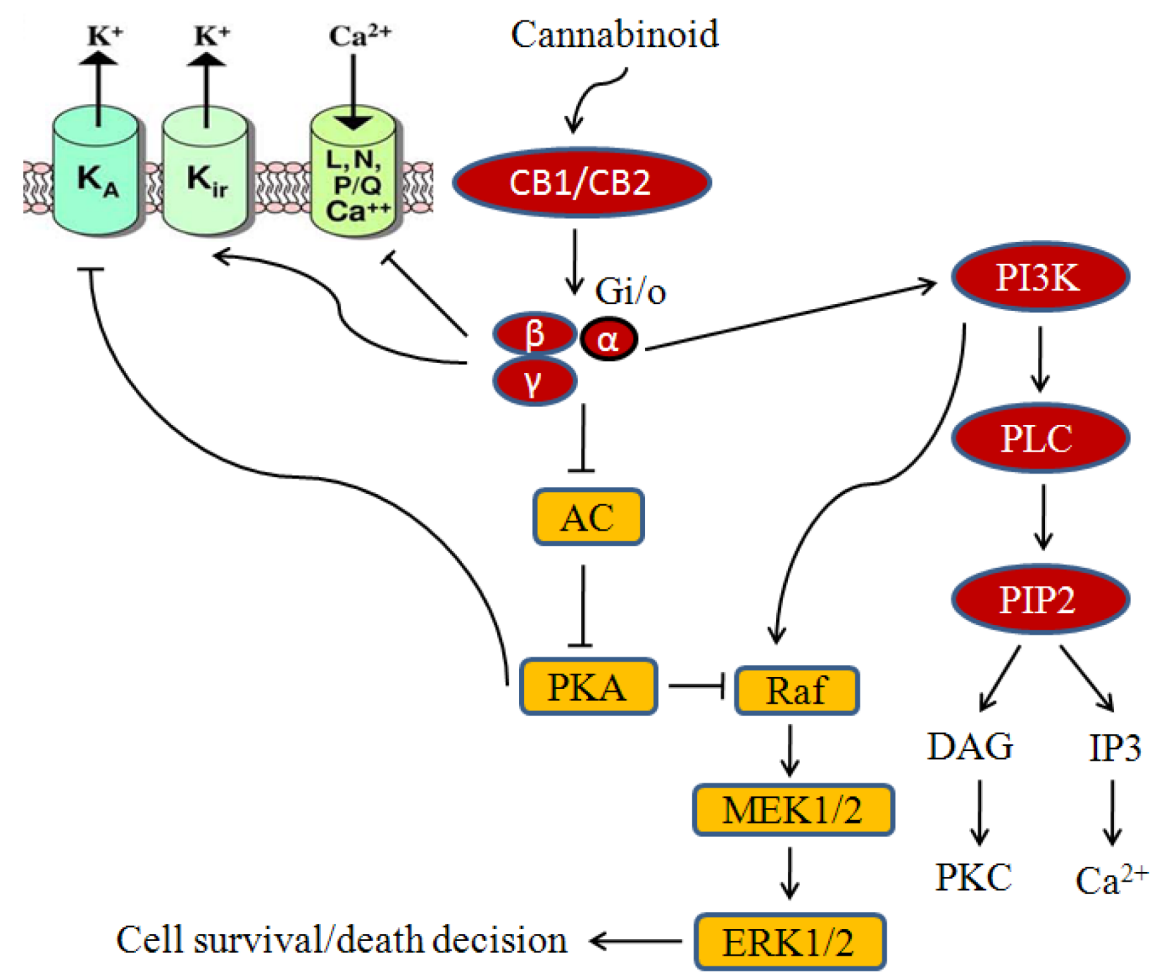

Fig.2: Cannabinoid mediated signaling in cancer cells. Cannabinoids activate CB1 or CB2 receptor which in turn modulates diverse signaling targets. 


\section{Cannabinoid receptor mediated signaling in cancer}

The widespread distribution of cannabinoid receptors (CB1/2,TRPV1) regulate a variety of central and peripheral physiological functions, including neuronal development, neuromodulatory processes, energy metabolism as well as cardiovascular, respiratory, reproductive functions. $\mathrm{CB} 1 / 2$ receptors are also responsible for proliferation, motility, invasion, adhesion and apoptosis of cancer cells both in vitro and in vivo (Table II). CB1/2 receptor activation leads to various events like affecting $\mathrm{Ca}^{+}$and $\mathrm{K}^{+}$channels, modulation of adenyl cyclase and cyclic AMP (c-AMP) levels in most tissues and models, regulation of members mitogen activated protein kinase family (MAPKs), like extracellular signal regulated kinase-1 and -2 (ERK1/2), p38, MAPK and c-Jun $\mathrm{N}$ terminal kinase (JNK) [37-38] as shown in Fig.2.

\section{Role of cannabinoids in regulation of cancer growth}

One of the important aspects of an effective antitumor drug is its ability to inhibit proliferation of cancer cells. Cancer cells proliferate rapidly in uncontrolled manner. Also, these cells escape death mechanism which a normal cell undergoes like apoptosis. Apoptosis is a kind of programmed cell death (PCD) mechanism which involves activation of caspase dependent and independent pathways [39]. Cannabinoids have been proved to be antiproliferative and apoptotic drugs. This section comprises of the detailed role of cannabinoids in modulation of tumor proliferation, cell cycle and apoptosis in various cancer types.

\section{Cannabinoids and breast cancer}

Breast cancer is one of the most common human malignancies and the second leading cause of cancerrelated deaths in women, and its incidence in the developing world is on the rise [40-41]. It represents approximately $30 \%$ of newly diagnosed cancers each year. It is mainly classified into three main subtypes according to their molecular profiles: hormone receptor-positive, HER2-positive (ErbB2-positive, a member of EGFR family) and triple-negative tumors [42-43]. Cannabinoidbased medicines have been useful for the treatment of these three breast cancer subtypes.

$\mathrm{CB} 1$ and $\mathrm{CB} 2$ receptor expression has been described in different breast cancer tissue and cell line by immunohistochemistry, RT-PCR and western blot. CB1 expression was detected in $14 \%$ of human Her-2 positive breast cancer tumor tissue and $28 \%$ of human breast carcinoma [26, 44]. But no correlation between CB1 expression and ErbB2 expression was found [44]. $\mathrm{CB} 1$ receptors are also present in different breast cancer cell lines (MCF-7, T-47D, MDA-MB-231, TSA-E1, MDA-MB-468) and in human breast tissues [26, 45-51]. By contrast, CB2 immunoreactivity was detected in $72 \%$ of human breast tumor tissue and $91 \%$ of ErbB2-positive tumor tissue, suggesting a link between CB2 and ErbB2expression [44].The expression of CB2 receptor was also analyzed in different breast carcinoma cell lines (MCF7, T-47D, MDA-MB-231, MDA-MB-468, EVSA-T, SkBr3) and human breast tissues [26, 44-46, 49, 51-52]. The putative novel cannabinoid receptor subtype GPR55 was highly expressed in a MDA-MB-231 cells, but it is expressed at lower (30-fold) levels in MCF-7 cells [53].

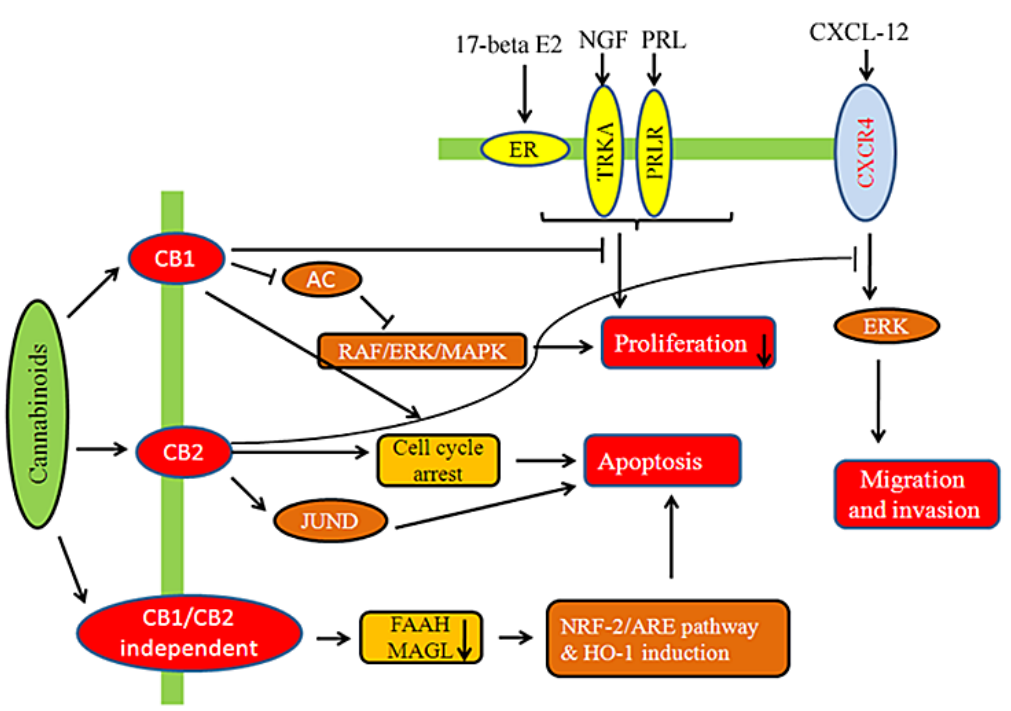

Fig.3: Modulatory effect of cannabinoids on hormone sensitive breast cancer cells. Cannabinoids are involved in receptor dependent/independent regulation of various hallmarks of breast cancer like proliferation, migration, invasion, etc. 
Cannabinoids modulate the growth of hormone sensitive breast cancer cells as shown in Fig.3 and 4. JWH-O15 inhibits hormone sensitive breast cancer metastasis by modulating CXCL12/CXCR4 signaling axis $[27,54]$. Endocannabinoids such as anandamide (AEA) are important lipid ligands regulating cell proliferation, differentiation and apoptosis. Their levels are regulated by hydrolase enzymes, the fatty acid amide hydrolase (FAAH) and monoacylglycerol lipase (MGL). Breast tumor cells express FAAH abundantly. Inhibition of FAAH (siRNA-FAAH or FAAH inhibitor URB597) induced cell death by activating nuclear factor (erythroidderived 2)-like 2 ( $\mathrm{Nrf} 2$ )/antioxidant responsive element (ARE) pathway and heme oxygenase-1 (HO-1) induction and transcription [55]. Anandamide inhibits basal and nerve growth factor (NGF) induced proliferation of MCF7 and EFM-19 cells in culture through CB1 receptor and $\Delta^{9}$-THC inhibits 17 beta-estradiol-induced proliferation of MCF7 and MCF7-AR1 cells $[45,56-58] . \Delta^{9}$-THC also inhibits cell proliferation of $\mathrm{ER}^{-} / \mathrm{PR}^{+}$breast cancer cells. The effects of anandamide and $\Delta^{9}$-THC were mediated by blocking transition from one phase of cell cycle to another, G1-S and G2-M respectively [49, 56, 59-60]. Cell cycle arrest is responsible for apoptotic cell death. The analog of anandamide, Met-F-AEA reduces MDAMB-231 proliferation by arresting cells in the $\mathrm{S}$ phase of the cell cycle [60]. Anandamide inhibits adenylyl cyclase (AC) and thus activating the Raf-1/ERK/MAP pathway in $\mathrm{ER}^{+} / \mathrm{PR}^{+}$breast cancer cells whilst $\mathrm{THC}$ activates the transcription factor JunD to finally execute action towards apoptosis in $\mathrm{ER}^{-} / \mathrm{PR}^{+}$breast cancer cells $[49,56,59]$. One study shows that anandamide inhibits proliferation of MDA-MB31 cells by modulating Wnt/ $\beta$-catenin signaling pathway [61]. This effect is occurred by inhibition of the cyclin-dependent kinase CDK2 [50,60].

Synthetic cannabinoids containing naphthoylindole, JWH-018, JWH-073, JWH-122 and JWH-210 and of one benzoylindole AM-694 shows anti-estrogenic property in MCF-7 cells [62]. Cannabinoid induced signaling in $\mathrm{ER}^{+}$ breast cancer cells is shown in Fig.3. WIN 55,212-2 and JWH-133 also produce an inhibition of MDA-MB-231 proliferation by blocking the progression trough the cell cycle, G1 to $\mathrm{S}$ phase transition and induced apoptosis [26]. The anti-proliferative effect of WIN 55,212-2 and JWH-133 is validated in both in xenograft-based and PyMT genetically engineered model of triple-negative breast cancer modulate through the COX-2/PGE2 signaling pathway [26]. JWH-015 also reduces breast cancer-induced bone pain, bone loss, and breast cancer proliferation via cytokine/chemokine suppression.

CBD inhibits AKT and mTOR signaling as well as decreased levels of phosphorylated mTOR and 4EBP1, and cyclin D1. CBD enhances the interaction between beclin1 and Vps34; it inhibits the association between beclin1 and Bcl-2 [63]. LPI stimulates proliferation and this effect was blocked by CBD [53]. Thus, cannabinoids along with COX-2 inhibitors or other chemotherapeutic agents may represent as novel chemopreventive tools for the treatment of breast cancer. Fig. 4 shows the effect of cannabinoids on HER-2 and triple negative breast cancer pathway.

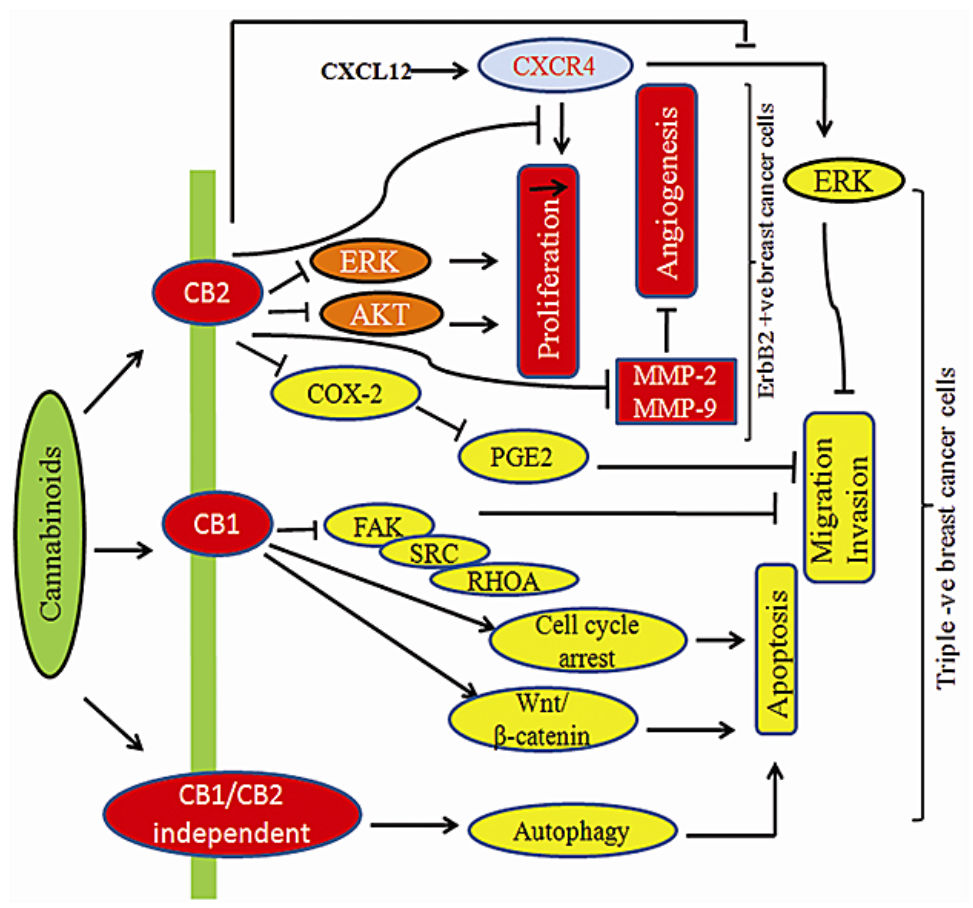

Fig.4: Modulatory effect of cannabinoids on HER-2 +ve and Triple -ve breast cancer cells. Cannabinoids inhibit key signaling targets in triple negative breast cancer which has worse prognosis in patients. 


\section{Cannabinoids and prostate cancer}

Prostate cancer is the most common malignancy among men of all races and is one of the leading causes of cancer death in this population. CB1 and CB2 expression levels were higher in prostate cancer tissues and several cell lines including PC-3, DU-145, LNCaP, CWR22Rv1, CA-HPV-10 as compared with normal prostate epithelial cells [45, 64-71]. Moreover, the putative cannabinoid receptor GPR55 is also expressed in PC-3 and DU-145 cells [72]. $\Delta^{9}-$ THC, WIN-55,212-2, R(+)Methanandamide , Cannabidiol (CBD), Anandamide, JWH-015, HU120, 2-AG and its stable analogue noladin have exerted anti-proliferative, apoptotic and anti-invasive effects in different prostate cancer cells both in vitro and in vivo [45, 68-69, 73-77]. $\Delta^{9}-$ THC induced apoptosis via a receptor-independent manner whilst in another study, the same group reported that activation of cannabinoid receptors in PC-3 cells stimulated the PI3K/Akt pathway with sequential involvement of Raf-1/ERK1/2 and nerve growth factor induction $[66,68]$. Treatment of WIN55,212-2 resulted in sustained activation of ERK1/2 and inhibition of AKT, which was associated with the induction of phosphatases [74, 78]. CBD also mimicked the same effect in LNCaP cells as WIN-55,212-2 [78]. The effects of anandamide in LNCaP, DU145, and PC3 cells were mediated through down-regulation of epidermal growth factor receptor (EGFR) and accumulation of ceramide [77]. JWH-015 triggered a de novo synthesis of ceramide, which induced cell death, followed by JNK (c-Jun N-terminal kinase) activation and Akt inhibition [76]. Effects of R(+)-Methanandamide and JWH-015 were rescued by treatment with SR 144528 in PC-3 cells $[76,79]$. Interestingly, (R)-methanandamide was shown to have a mitogenic effect on $\mathrm{LNCaP}$ cells at very low doses $[46,75]$. FAAH is a serine hydrolase that metabolizes $\mathrm{N}$-acylethanolamines including AEA, OEA and PEA to fatty acids plus ethanolamine. A recent report showed that FAAH is also over-expressed in prostate cancer cells and the inhibition of FAAH can enhance the survival of cancer patient [80-81].

\section{Cannabinoids and lung cancer}

Lung cancer has one of the highest mortality rates among cancer-suffering patients. Cannabinoids (CBs) could halt tumor development without side effects via specific targeting of $\mathrm{CB} 1 / \mathrm{CB} 2$ receptor. Studies suggest the involvement of COX-2 and PPAR- $\gamma$ in CBD's proapoptotic and tumor-regressive action in A549, H460 cells and primary cells from a patient with lung cancer [82]. Moreover, CBD caused up-regulation of COX2 and PPAR- $\gamma$ in tumor tissue and tumor regression in A549-xenografted nude mice [82]. JWH-133 induced anti-proliferative potential in A549 cell line via DNA fragmentation [83]. Recently, we published results on the role of FAAH in regulating the effects of AEA in NSCLC. We showed that blocking FAAH increases the levels of AEA, which in turn inhibits EGFR signaling pathway, ultimately leading to cell cycle arrest and apoptosis [84]. These results generate a rationale for further in vivo efficacy studies with this compound in preclinical cancer models.

\section{Cannabinoids and skin cancer}

Melanoma is the mainly cause of skin cancer-related deaths worldwide. $\mathrm{CB} 1$ and $\mathrm{CB} 2$ receptors are expressed in normal skin and skin tumors of mice and humans [85]. Activation of $\mathrm{CB} 1 / \mathrm{CB} 2$ receptors induced the apoptotic death of tumorigenic epidermal cells, without affecting the nontransformed epidermal cells. WIN-55,212-2 or JWH133 induced anti-proliferative effect in epidermal cell lines (PDV.C57 and $\mathrm{HaCa} 4$ ) and reduces malignant tumors in nude mice [85]. WIN-55,212-2 or JWH-133 induced G1 cell cycle arrest on melanoma cells, via inhibition of $\mathrm{p}$-Akt and hypophosphorylation of the $\mathrm{pRb}$ retinoblastoma protein tumor suppressor [85].

\section{Cannabinoids and pancreatic cancer}

Pancreatic cancer is one of the most aggressive and devastating human malignancies. $\mathrm{CB} 1$ and $\mathrm{CB} 2$ receptors were expressed in normal and pancreatic cancer tissues, analyzed by RT-PCR [86]. Cannabinoid receptors on pancreatic cancer cells may affect prognosis and pain status of PDAC patients [86]. Cannabinoid administration leads to apoptosis of pancreatic tumor cells via CB2 receptor and ceramide-dependent up-regulation of $\mathrm{p} 8$ and ATF-4 and TRB 3 stress-related genes [87]. Another study showed that $\mathrm{CB} 1$ receptor antagonist AM251-induced cell death in pancreatic MIAPaCa-2 cells occurred via receptor-independent manner [88].

\section{Cannabinoids and bone cancer}

Chondrosarcoma and osteosarcoma are the most frequent primary bone cancers [89]. Bone metastases are a frequent complication of cancer and the most frequent type of pain related to cancer. Breast cancer and prostate cancer mainly metastasize to bone which act as a fertile soil for the growth of secondary tumors [90]. The skeletal endocannabinoid system plays a significant role in regulating bone mass and bone turnover. The expression levels of $\mathrm{CB} 1$ and $\mathrm{CB} 2$ receptors were analyzed in bone cancer patient using immunohistochemistry [91]. Bone metastatic patient has severe pain so cannabinoids can attenuate pain and hyperalgesia [92]. Sativex is the combination of delta-9-tetra-hydrocannabinol and 
cannabidiol, used to treat pain in cancer [92]. WIN55,2122 induces apoptosis in the NCTC-2472 sarcoma cell line and AM1241 produced a reduction in bone loss in bone tumor animal model (NCTC-2472 cell line injected in to femur of mice) [93-94]. Effects of subcutaneously administered WIN55,212-2 on weight bearing and mechanical hyperalgesia were consistent with cannabinoid receptor mediated anti-nociception [93]. WIN55,212-2 also attenuates tumour-evoked mechanical hyperalgesia following local (intraplantar) administration through activation of CB1 and CB2 receptors [95]. Injection of CP55 940 produced anti-nociceptive properties in the tail flick test and suppressed mechanical hyperalgesia in NCTC-2472 or melanoma B16-F10 xenografted bone tumor model [96]. Indeed, intraplantar administration of AEA reduces mechanical hyperalgesia, URB597 increases AEA levels and decreases hyperalgesia in a model of calcaneous bone cancer pain [91]. However, intrathecal administration of either URB597 or MGL (URB602) inhibitors failed to produce anti-nociception when tested for spontaneous flinches, limb use and weight bearing [97]. Moreover, the CB1 agonist arachidonoyl2-chloroethylamide (ACEA) produces anti-nociceptive properties following intrathecal administration in this model; ACEA suppressed spontaneous flinches and increased limb use and weight bearing [97]. AM1241 produces significantly reduced bone loss and decreased the incidence of cancer-induced bone fractures [94, 98]. Administration of JWH-015 and AM1241 attenuated tumor-evoked tactile allodynia and thermal hyperalgesia by reducing NR2B-dependent activity [98-99]. CB2 agonist, JWH-015 reduced breast cancer induced bone pain, bone loss, and breast cancer cell proliferation via cytokine/chemokine suppression in murine mammary cell line implanted into the femur intramedullary space [100]. JWH-015 increased survival without the major side effects of current therapeutic options.

\section{Cannabinoids and glioma}

Gliomas are the most important group of malignant primary brain tumors and one of the most aggressive forms of cancer, exhibit high resistance to conventional chemotherapies. In glioblastoma endothelial cells, CB1 and $\mathrm{CB} 2$ receptors were present in about 38\% and 54\% of the cells respectively, analyzed by immunohistochemistry. CB2 expression levels were higher in glioblastoma tissues in comparison to $\mathrm{CB} 1$. Selective CB2 agonists may become important targets for the treatment of glioma. Cannabinoids, inhibit tumor growth in animal models by inducing apoptosis of tumor cells and impairing tumor angiogenesis. Administration of $\Delta^{9}$-THC and JWH133 inhibits MMP-2 expression in in vivo model of glioma [101-103]. The growth inhibitory effect of these cannabinoids is prevented by blocking ceramide synthesis, and the expression of the stress protein p8 [102-103]. Both
$\Delta^{9}$-THC and WIN-55,212-2 resulted in sustained activation of ERK1/2 and inhibition of AKT [104]. Furthermore, $\Delta^{9}$-THC induced eukaryotic translation initiation factor 2alpha (eIF2alpha) phosphorylation and thereby activated an ER stress response that promoted autophagy via tribbles homolog 3-dependent (TRB3-dependent) inhibition of the Akt/mammalian target of rapamycin complex 1 (mTORC1) axis [105]. The activation of this pathway was necessary for the antitumor action of cannabinoids in vivo [105]. In contrast to that CBD treatment induces apoptosis in glioma cells in vitro and tumor regression in vivo through activation of caspases and reactive oxygen species via receptor-independent manner Furthermore, studies revealed that CBD induced TRPV2-dependent $\mathrm{Ca}^{2+}$ influx which triggers the drug uptake and synergizes with cytotoxic agents to induce apoptosis of glioma cells [106]. Authors thought that CBD which do not specifically interact with $\mathrm{CB} 1 / \mathrm{CB} 2$ receptors, can modulate the activity of $\Delta^{9}$-THC. On that basis Marcu et al determined the growth inhibitory effect of CBD in combination with $\Delta^{9}$-THC in the U251 and SF126 glioblastoma cell lines [107]. Furthermore, the combined treatment of $\Delta^{9}$-THC and temozolomide (TMZ) exert a strong antitumoral action in glioma xenografts by inducing autophagy [108]. The submaximal doses of $\Delta^{9}$-THC and CBD in combination with $\mathrm{TMZ}$ produced a strong antitumoral action in both TMZ-sensitive and TMZ-resistant tumors [108]. Treatment of KM-233 (novel cannabinoid ligand) caused a time dependent change in the phosphorylation profiles of MEK, ERK1/2, Akt, BAD, STAT3, and p70S6K in U87MG human GBM cells [109]. At $12 \mathrm{mg} / \mathrm{kg}$ daily dose of KM-233 for 20 days revealed around $80 \%$ reduction in tumor size in the orthotopic model of U87MG [109]. Glioma cells develop resistance to cannabinoid treatment due to the upregulation of Amphiregulin (EGFR family ligand) and the growth factor midkine (Mdk) [110-111]. Amphiregulin expression was associated with increased ERK activation and Mdk mediated its protective effect through ALK which interferes with autophagic cell death [112]. The silencing of amphiregulin and Mdk or ALK pharmacological inhibition can overcome drug resistance of glioma to cannabinoids antitumoral action. Furthermore, to improve the efficacy of cannabinoids action, microencapsulation methods were used which facilitates a sustained release of the two cannabinoids for several days [113]. Administration of CBD- and THCloaded poly- $\varepsilon$-caprolactone microparticles reduced tumor growth, cell proliferation and increased apoptosis in mice bearing glioma xenografts with the same efficacy than a daily local administration of these drugs in solution [113].

\section{Cannabinoids and lymphoma}

$\mathrm{CB} 1$ and $\mathrm{CB} 2$ receptors were over-expressed in mantle cell lymphoma (MCL), and B cell non-Hodgkin lymphoma [114-115]. $\Delta^{9}$-THC inhibits cell viability and 
increased apoptosis both in vitro in EL4 and MCL cells and EL4 tumor bearing mice. In next studies the combination of $\Delta^{9}$-THC and other cytotoxic agents induced apoptosis in leukemia cells by MAPK/ERK pathway $[114,116]$. In addition $\mathrm{R}(+)$-methanandamide and WIN-55,2122 induced apoptosis in MCL cells, was associated with ceramide accumulation and p38, depolarization of the mitochondrial membrane, and caspase activation [117]. $\mathrm{R}(+)$-methanandamide also induced apoptosis in CLL cells [118]. In contrast, cannabinoids decreased cell viability as assessed by metabolic activity. The persistent expression of mammalian homolog of Atg8 with microtubuleassociated protein-1 light chain-3 II (LC3 II) and p62, as well as the lack of protection from chloroquine, indicates that lysosomal degradation is not involved in this cytoplasmic vacuolation process, distinguishing from classical autophagy [119]. Paraptosis-like cell death-a third type of a programmed cell death occurred in response to cannabinoids [119].

\section{Cannabinoids and oral cancer}

Oral cancer is mainly occurs in the mouth including lips, tongue and throat. Smoking, tobacco chewing and alcohol consumption increases the incidence of oral cancer. Radiation therapy and surgery is the common treatment for oral cancer. $\Delta^{9}$-THC induced apoptosis in oral squamous cell carcinoma (OSCC), a malignant form of oral cancer [120].

\section{Cannabinoids and head and neck cancer}

Marijuana smoking increases the incidence of head and neck cancer in young people but its constituent, cannabinoids have anti-tumor properties. One study reports that moderate marijuana use is associated with reduced risk of HNSCC [121].

\section{Cannabinoids and thyroid carcinoma}

Thyroid carcinoma is the most aggressive form which occurs in thyroid gland. IL-12 gene transfer in to anaplastic thyroid carcinoma cell line (ARO) has antitumorigenic effect [122]. This effect was observed due to the activation of cannabinoid receptor. Furthermore they have reported that $\mathrm{CB} 2$ agonist JWH-133 and CB1/CB2 agonist WIN-55,212-2 induced apoptosis in ARO and ARO/IL-12 cells [122]. 2-methyl-2'-F-anandamide (MetF-AEA) also induced apoptosis in thyroid carcinoma cells via activation of p53 and p21 mediated pathway [123].

\section{Role of cannabinoids in pro-metastatic mechanisms like angiogenesis, migration and invasion}

Migration and invasion are characteristic features of cancer cells. Carcinoma cells that are invasive have higher migratory potential which helps them to disseminate into the surrounding tissues and spread to other organs, ultimately leading to metastasis [124]. Angiogenesis, which involves growth of new vasculature has been shown to be closely related to cancer metastasis. Developing novel anti-invasive and anti-angiogenic targets would be more effective in inhibiting metastasis at earlier stage [125].

In breast cancer, Met-F-AEA leads to the inhibition of the focal adhesion kinase (FAK) and RhoA-ROCK pathways [126]. JWH-015 reduces CXCL12-induced cell migration and invasion of a highly metastatic MDA-MB231-derived cell line by inhibiting ERK and cytoskeletal focal adhesion and stress fiber formation [127]. Novel synthetic hexahydrocannabinol analogs, LYR-7 and LYR8 reduced tumor growth by targeting VEGF-mediated angiogenesis signaling in MCF-7 and MCF-7 Tam resistant cells [128]. Cannabidiolic acid (CBDA) inhibits migration of MDA-MB-231 cells via inhibition of cAMPdependent protein kinase $\mathrm{A}$, coupled with an activation of the small GTPase, RhoA [129]. Lysophosphatidylinositol (LPI), the putative endogenous ligand for GPR55, also stimulates cell migration and invasion in a MDA-MB-231 cell line and its effect is blocked by pretreatment with cannabidiol (CBD) $[53,130]$. Recent study shows that THC and JWH-133 exert anti-proliferative, pro-apoptotic, anti-angiogenic, and anti-invasive effects in both in vitro and in vivo models of ErbB-2 breast cancer by modulating AKT, phospho-S6 ribosomal protein, MMP-2 and MMP-9 expression levels shown in Fig.3 [44, 131-132].

In lung cancer, CBD inhibits invasion of A549 cells both in vitro and in vivo that was accompanied by upregulation of tissue inhibitor of matrix metalloproteinase-1 (TIMP-1) and decreased expression of plasminogen activator inhibitor-1 (PAI-1) [133-134]. P38 and ERK1/2 were identified as upstream targets for up-regulation of TIMP-1 [134]. But recent report suggests that CBD induced TIMP-1 via upregulation of intercellular adhesion molecule-1 (ICAM-1) [135]. JWH-133 induced antiangiogenic potential in A549 cell line via inhibition of MMP-2 secretion respectively [83].

In skin cancer, treatment of WIN-55,212-2 or JWH133 caused impairment of tumor vascularization and decreased expression of proangiogenic factors such as VEGF, placental growth factor, and angiopoietin-2 [85].

In glioma, [136], one study reveals that CBD also inhibits angiogenesis by modulating MMP-2 pathway and Id-1 gene expression in glioblastoma cells [137138]. Administration of CBD- and THC-loaded poly- $\varepsilon-$ 
caprolactone microparticles reduced tumor growth and angiogenesis in mice bearing glioma xenografts with the same efficacy than a daily local administration of these drugs in solution [113].

\section{Role of cannabinoids in cancer metastasis}

Met-F-AEA, WIN 55,212-2, JWH-133 and JWH-015 inhibit the migration and invasion of MDAMB231 breast cancer cells to distant sites such as lung [27, 50, 126, 139-140]. CBD inhibits cell proliferation and invasion of 4T1 cells (mammary metastatic cell line) and reduces primary tumor volume as well as lung metastasis in 4T1-xenografted orthotopic model of nude mice [141-142]. This anti-metastatic effect was mediated by downregulation of Id-1 (a basic helix-loophelix transcription factor inhibitor), ERK and also by inhibiting the ROS pathway. Furthermore, CBD reduced the number of metastatic foci in 4T1- tail vein injected syngenic model. In lung cancer, JWH-015 and Win55,2122 inhibit in vitro chemotaxis, chemoinvasion and in vivo tumor growth and lung metastasis via inhibition of AKT, matrix metalloproteinase 9 expression (MMP-9), but the pretreatment of $\mathrm{CB} 1 / \mathrm{CB} 2$ selective antagonists, AM251 and AM630 antagonized their effects [143]. $\Delta^{9}$ THC inhibits growth of Lewis lung adenocarcinoma via inhibition of DNA synthesis and it suppresses growth and metastasis of A549 and SW-1573 (human lung cancer cell lines) both in vitro and in vivo due to inhibition of epidermal growth factor-induced phosphorylation of ERK1/2, c-Jun-NH2-kinase1/2 and Akt [144-145].

\section{Role of cannabinoids in stemness and cancer}

Cancer stem cells (CSC) are part of the tumor cell population. Though they might be very less in number, they have the ability to self renew and replicate to produce enormous cancer cell types. CSCs have been shown to be drug resistant with higher invasive and metastatic potential [146]. Studies show that cannabinoid receptors are involved in differentiation of neural progenitors from ectoderm and hematopoietic progenitors from mesoderm. $\mathrm{CB} 1$ and $\mathrm{CB} 2$ receptor activation modulate proliferation and differentiation of daughter progenitors. CannabinoidsHU210, WIN55,212-2, AEA and methAEA induced concentration dependent cytotoxicity in P19 embryonal carcinoma (EC) cells [147]. It involved partial regulation by cannabinoid receptors leading to oxidative stress, necrosis coupled with apoptosis. Both CB1 and CB2 receptors are expressed in glioma stem like cells (GSC). HU-210 and JWH-133 helped in neural differentiation of GSC and blocked GSC mediated gliomagenesis [148]. These open further investigation on the function of cannabinoids and the link between stem cell and tumor progression.

\section{Role of cannabinoids in energy metabolism and cancer}

One of the important by-products in energy metabolism is a set of compounds called Reactive Oxygen Species (ROS) which is produced from mitochondria and consists of $\mathrm{H}_{2} \mathrm{O}_{2}$, superoxide $\mathrm{O}_{2}^{-}$, hydroxyl radical $\mathrm{O}_{2}^{-}$, etc. Increased ROS production has been associated with triggering of apoptosis [149]. CBD modulates ERK and reactive oxygen species (ROS) pathways, which lead to down-regulation of Id-1 expression. Id-1, an inhibitor of basic helix-loop-helix transcription factors, has recently been shown to be a key regulator of the metastatic potential of breast and additional cancers [141-142]. Arachidonoyl cyclopropamide (ACPA) or GW405833 (GW) induced AMPK mediated autophagy in pancreatic adenocarcinoma cells is strictly related to the inhibition of energy metabolism through a ROS-dependent increase of the AMP/ATP ratio [150]. The combination of cannabinoids and gemcitabine, a nucleoside analogue used in cancer chemotherapy, synergistically inhibit pancreatic adenocarcinoma cell growth by a ROS-mediated autophagy induction without affecting normal fibroblasts [151]. Cannabidiol (CBD)-induced endoplasmic reticulum stress mediated cell death of MDA-MB231 breast cancer cells, with the coexistence of autophagy and apoptosis [63]. Recently one published report shows that $\Delta^{9}$-THC and $\Delta^{8}$-THC inhibited mitochondrial oxygen consumption rate via receptor independent manner in oral cancer cells [152]. In primary lymphocytes, treatment with CBD induced caspase 8 induced apoptosis which was mediated by oxidative stress. Similar result has been reported in glioma cells where CBD causes oxidative stress and higher enzymatic activities of glutathione reductase and glutathione peroxidase. In NSCLC cell line H460, agonists AEA, THC and HU-210 modulated the activity of mitochondrial complexes I and II-III, decreasing the mitochondrial membrane potential. $\Delta^{9}$ THC and cannabidiol acted synergistically to inhibit cell proliferation, modulations of the cell cycle and induction of reactive oxygen species and apoptosis as well as specific modulations of extracellular signal-regulated kinase and caspase activities in glioblastoma [107]. KM233 induced mitochondrial depolarization, cleaved caspase 3 , significant cytoskeletal contractions, and redistribution of the Golgi-endoplasmic reticulum structures in U87MG human GBM cells [109].

\section{Role of cannabinoids in immune environment and cancer}

Cancer is a type of inflammatory disease, where immune cells infiltrate into the tumor site and secrete factors which enhance the prospects of proliferation, angiogenesis and metastasis [153]. Hence, it is important 
to identify anti-cancer agents that target the immune related cancer environment. In glioma, WIN-55,212-2 caused accumulation of ceramide which is essential for cell death and it also had anti-inflammatory effects [154]. WIN55,212-2, abolished the PGN-activated cell growth which activates a number of inflammatory pathways, including NF- $\mathrm{BB}$ (aggravates tumors) and this effect was reversed by $\mathrm{CB} 1$ antagonist AM281 but not by the CB2 antagonist, AM630 [155]. Anandamide reduces proliferation and production of cytokines like IL-2, TNF- $\alpha$ and INF- $\gamma$ in human T lymphocytes by activating CB2 receptor [156]. In astrocytoma and glioblastoma cells, WIN55,212-2 inhibited IL-1 mediated activation of adhesion molecules and chemokines like ICAM-1, VCAM-I and IL-8, which was receptor independent [157]. In murine $\mathrm{T}$ cells, cannabinol decreased IL-2 production by inhibiting nuclear factor of activated T-cells (NFAT) and activator protein-1 (AP-1) [158]. In CD8+ T lymphocytes, JWH-133 downregulated SDF-1 induced $\mathrm{m}$ migration in CB2 receptor dependent manner [159].

\section{CONCLUSIONS AND FUTURE DIRECTIONS}

Cannabinoids exert a direct anti-proliferative effect on tumors of different origin. They have been shown to be anti-migratory and anti-invasive and inhibit MMPs which in turn degrade the extra-cellular matrix (ECM), thus affecting metastasis of cancer to the distant organs. Also, cannabinoids modulate other major processes in our body like energy metabolism, inflammation, etc. These data are derived not only from cell culture systems but also from more complex and clinically relevant animal models. Before cannabinoids could be used in clinical trials, there is need to explore more knowledge on several issues such as anti-tumorigenic and anti-metastatic mechanisms as well as which type of cancer patient populations would be more responsive for cannabinoid based therapies. Data presented in this review suggest that cannabinoids derived from different sources regulate differently signaling pathways, modulate different tumor cell types and host physiological system. It is important to understand which of the cannabinoid receptors are expressed and activated in different tumors as each receptor follows a different signaling mechanism. Furthermore, endocannabinoids- AEA and 2-AG are broken down into secondary metabolites like prostaglandin $\left(\mathrm{PGE}_{2}\right)$ and epoxyeicosatetraenoic acid (EE) which enhance tumor growth and metastasis in diverse cancer types. Understanding the exact signaling by which cannabinoids function will eventually lead to targeted clinical approach. Also, the difference in cellular response to cannabinoids in different cancer types might be due to the effect of the tumor environment which involves inflammatory cells, fibroblasts, endothelial cells, macrophages, etc. Thus, there is a need for an integrative understanding of the role of cannabinoids with respect to the tumor and its microenvironment. The diversity of affecting multiple signaling pathways might pave way for developing cannabinoids that selectively obstruct a particular pathway, thus opening avenues for specific targeted treatments.

Moreover, cannabinoids are more specific to cancer cells than normal cells. The administration of single cannabinoids might produce limited relief compared to the administration of crude extract of plant containing multiple cannabinoids, terpenes and flavanoids. Thus, combination of cannabinoids with other chemotherapeutic drugs might provide a potent clinical outcome, reduce toxicity, increase specificity and overcome drug resistance complications. Additional findings in in vitro and in vivo models are needed to support studies at preclinical setting.

\section{ACKNOWLEDGEMENTS}

This work was supported by grants from the NIH (CA163010 and CA153490) and American Lung Association Discovery Award to RKG. This work was also supported by a grant from Government of India, Department of Science and Technology to BC.

\section{CONFLICTS OF INTEREST}

The authors disclose no competing interests.

\section{REFERENCES}

1. Deiana S. Medical use of cannabis. Cannabidiol: a new light for schizophrenia? Drug Test Anal. 2013; 5(1):46-51.

2. Adams R. Marihuana: Harvey Lecture, February 19, 1942. Bull N Y Acad Med. 1942; 18(11):705-730.

3. Ware MA, Doyle CR, Woods R, Lynch ME and Clark AJ. Cannabis use for chronic non-cancer pain: results of a prospective survey. Pain. 2003; 102(1-2):211-216.

4. Sarfaraz S, Adhami VM, Syed DN, Afaq F and Mukhtar H. Cannabinoids for cancer treatment: progress and promise. Cancer Res. 2008; 68(2):339-342.

5. Bosier B, Muccioli GG, Hermans E and Lambert DM. Functionally selective cannabinoid receptor signalling: therapeutic implications and opportunities. Biochem Pharmacol. 2010; 80(1):1-12.

6. Matsuda LA, Lolait SJ, Brownstein MJ, Young AC and Bonner TI. Structure of a cannabinoid receptor and functional expression of the cloned cDNA. Nature. 1990; 346(6284):561-564.

7. Devane WA, Hanus L, Breuer A, Pertwee RG, Stevenson LA, Griffin G, Gibson D, Mandelbaum A, Etinger A and Mechoulam R. Isolation and structure of a brain constituent that binds to the cannabinoid receptor. Science. 1992; 258(5090):1946-1949. 
8. Mackie K. Distribution of cannabinoid receptors in the central and peripheral nervous system. Handb Exp Pharmacol. 2005; (168):299-325.

9. Munro S, Thomas KL and Abu-Shaar M. Molecular characterization of a peripheral receptor for cannabinoids. Nature. 1993; 365(6441):61-65.

10. Felder CC and Glass M. Cannabinoid receptors and their endogenous agonists. Annu Rev Pharmacol Toxicol. 1998; 38:179-200.

11. Pacher P, Batkai S and Kunos G. The endocannabinoid system as an emerging target of pharmacotherapy. Pharmacol Rev. 2006; 58(3):389-462.

12. Velasco G, Sanchez C and Guzman M. Towards the use of cannabinoids as antitumour agents. Nat Rev Cancer. 2012; 12(6):436-444.

13. Di Marzo V, Melck D, De Petrocellis L and Bisogno T. Cannabimimetic fatty acid derivatives in cancer and inflammation. Prostaglandins Other Lipid Mediat. 2000; 61(1-2):43-61.

14. Christie MJ and Vaughan CW. Neurobiology Cannabinoids act backwards. Nature. 2001; 410(6828):527-530.

15. Ruminska A and Dobrzyn A. [The endocannabinoid system and its role in regulation of metabolism in peripheral tissues]. Postepy Biochem. 2012; 58(2):127-134.

16. Mechoulam R, Ben-Shabat S, Hanus L, Ligumsky M, Kaminski NE, Schatz AR, Gopher A, Almog S, Martin BR, Compton DR and et al. Identification of an endogenous 2-monoglyceride, present in canine gut, that binds to cannabinoid receptors. Biochem Pharmacol. 1995; 50(1):83-90.

17. Di Marzo V and Deutsch DG. Biochemistry of the endogenous ligands of cannabinoid receptors. Neurobiol Dis. 1998; 5(6 Pt B):386-404.

18. Facci L, Dal Toso R, Romanello S, Buriani A, Skaper SD and Leon A. Mast cells express a peripheral cannabinoid receptor with differential sensitivity to anandamide and palmitoylethanolamide. Proc Natl Acad Sci U S A. 1995; 92(8):3376-3380.

19. Bisogno T, Ventriglia M, Milone A, Mosca M, Cimino $\mathrm{G}$ and Di Marzo V. Occurrence and metabolism of anandamide and related acyl-ethanolamides in ovaries of the sea urchin Paracentrotus lividus. Biochim Biophys Acta. 1997; 1345(3):338-348.

20. Hanus L, Gopher A, Almog S and Mechoulam R. Two new unsaturated fatty acid ethanolamides in brain that bind to the cannabinoid receptor. J Med Chem. 1993; 36(20):30323034.

21. Pertwee R, Griffin G, Hanus L and Mechoulam R. Effects of two endogenous fatty acid ethanolamides on mouse vasa deferentia. Eur J Pharmacol. 1994; 259(2):115-120.

22. Cravatt BF, Prospero-Garcia O, Siuzdak G, Gilula NB, Henriksen SJ, Boger DL and Lerner RA. Chemical characterization of a family of brain lipids that induce sleep. Science. 1995; 268(5216):1506-1509.
23. Russo EB. Taming THC: potential cannabis synergy and phytocannabinoid-terpenoid entourage effects. Br J Pharmacol. 2011; 163(7):1344-1364.

24. Paronis CA, Nikas SP, Shukla VG and Makriyannis A. Delta(9)-Tetrahydrocannabinol acts as a partial agonist/ antagonist in mice. Behav Pharmacol. 2012; 23(8):802-805.

25. Ross RA, Gibson TM, Stevenson LA, Saha B, Crocker P, Razdan RK and Pertwee RG. Structural determinants of the partial agonist-inverse agonist properties of 6'-azidohex-2'yne-delta8-tetrahydrocannabinol at cannabinoid receptors. Br J Pharmacol. 1999; 128(3):735-743.

26. Qamri Z, Preet A, Nasser MW, Bass CE, Leone G, Barsky $\mathrm{SH}$ and Ganju RK. Synthetic cannabinoid receptor agonists inhibit tumor growth and metastasis of breast cancer. Mol Cancer Ther. 2009; 8(11):3117-3129.

27. Nasser MW, Qamri Z, Deol YS, Smith D, Shilo K, Zou $\mathrm{X}$ and Ganju RK. Crosstalk between chemokine receptor CXCR4 and cannabinoid receptor CB2 in modulating breast cancer growth and invasion. PLoS One. 2011; 6(9):e23901.

28. Howlett AC, Barth F, Bonner TI, Cabral G, Casellas P, Devane WA, Felder CC, Herkenham M, Mackie K, Martin BR, Mechoulam R and Pertwee RG. International Union of Pharmacology. XXVII. Classification of cannabinoid receptors. Pharmacol Rev. 2002; 54(2):161-202.

29. Griffin G, Fernando SR, Ross RA, McKay NG, Ashford ML, Shire D, Huffman JW, Yu S, Lainton JA and Pertwee RG. Evidence for the presence of CB2-like cannabinoid receptors on peripheral nerve terminals. Eur J Pharmacol. 1997; 339(1):53-61.

30. Sanchez C, de Ceballos ML, Gomez del Pulgar T, Rueda D, Corbacho C, Velasco G, Galve-Roperh I, Huffman JW, Ramon y Cajal S and Guzman M. Inhibition of glioma growth in vivo by selective activation of the $\mathrm{CB}(2)$ cannabinoid receptor. Cancer Res. 2001; 61(15):5784-5789.

31. Ross RA, Brockie HC, Stevenson LA, Murphy VL, Templeton F, Makriyannis A and Pertwee RG. Agonistinverse agonist characterization at $\mathrm{CB} 1$ and $\mathrm{CB} 2$ cannabinoid receptors of L759633, L759656, and AM630. Br J Pharmacol. 1999; 126(3):665-672.

32. Showalter VM, Compton DR, Martin BR and Abood ME. Evaluation of binding in a transfected cell line expressing a peripheral cannabinoid receptor (CB2): identification of cannabinoid receptor subtype selective ligands. J Pharmacol Exp Ther. 1996; 278(3):989-999.

33. Abadji V, Lin S, Taha G, Griffin G, Stevenson LA, Pertwee RG and Makriyannis A. (R)-methanandamide: a chiral novel anandamide possessing higher potency and metabolic stability. J Med Chem. 1994; 37(12):1889-1893.

34. Gatley SJ, Lan R, Pyatt B, Gifford AN, Volkow ND and Makriyannis A. Binding of the non-classical cannabinoid CP 55,940, and the diarylpyrazole AM251 to rodent brain cannabinoid receptors. Life Sci. 1997; 61(14):PL 191-197.

35. Rinaldi-Carmona M, Barth F, Heaulme M, Shire D, Calandra B, Congy C, Martinez S, Maruani J, Neliat G, 
Caput D and et al. SR141716A, a potent and selective antagonist of the brain cannabinoid receptor. FEBS Lett. 1994; 350(2-3):240-244.

36. Rinaldi-Carmona M, Barth F, Millan J, Derocq JM, Casellas P, Congy C, Oustric D, Sarran M, Bouaboula M, Calandra B, Portier M, Shire D, Breliere JC and Le Fur GL. SR 144528 , the first potent and selective antagonist of the CB2 cannabinoid receptor. J Pharmacol Exp Ther. 1998; 284(2):644-650.

37. Bosier B, Muccioli GG, Hermans E and Lambert DM. Functionally selective cannabinoid receptor signalling: therapeutic implications and opportunities. Biochem Pharmacol. 2010; 80(1):1-12.

38. Howlett AC. Cannabinoid receptor signaling. Handb Exp Pharmacol. 2005; (168):53-79.

39. Hanahan D and Weinberg RA. The hallmarks of cancer. Cell. 2000; 100(1):57-70.

40. Ocana A and Pandiella A. Identifying breast cancer druggable oncogenic alterations: lessons learned and future targeted options. Clin Cancer Res. 2008; 14(4):961-970.

41. Tan JM, Ng EY, Acharya RU, Keith LG and Holmes J. Comparative study on the use of analytical software to identify the different stages of breast cancer using discrete temperature data. J Med Syst. 2009; 33(2):141-153.

42. Baselga $J$ and Swain SM. Novel anticancer targets: revisiting ERBB2 and discovering ERBB3. Nat Rev Cancer. 2009; 9(7):463-475.

43. Caffarel MM, Andradas C, Perez-Gomez E, Guzman M and Sanchez C. Cannabinoids: a new hope for breast cancer therapy? Cancer Treat Rev. 2012; 38(7):911-918.

44. Caffarel MM, Andradas C, Mira E, Perez-Gomez E, Cerutti C, Moreno-Bueno G, Flores JM, Garcia-Real I, Palacios J, Manes S, Guzman M and Sanchez C. Cannabinoids reduce ErbB2-driven breast cancer progression through Akt inhibition. Mol Cancer. 2010; 9:196.

45. Melck D, De Petrocellis L, Orlando P, Bisogno T, Laezza C, Bifulco M and Di Marzo V. Suppression of nerve growth factor Trk receptors and prolactin receptors by endocannabinoids leads to inhibition of human breast and prostate cancer cell proliferation. Endocrinology. 2000; 141(1):118-126.

46. McKallip RJ, Nagarkatti $M$ and Nagarkatti PS. Delta9-tetrahydrocannabinol enhances breast cancer growth and metastasis by suppression of the antitumor immune response. J Immunol. 2005; 174(6):3281-3289.

47. Sarnataro D, Grimaldi C, Pisanti S, Gazzerro P, Laezza C, Zurzolo C and Bifulco M. Plasma membrane and lysosomal localization of CB1 cannabinoid receptor are dependent on lipid rafts and regulated by anandamide in human breast cancer cells. FEBS Lett. 2005; 579(28):6343-6349.

48. Sarnataro D, Pisanti S, Santoro A, Gazzerro P, Malfitano AM, Laezza C and Bifulco M. The cannabinoid CB1 receptor antagonist rimonabant (SR141716) inhibits human breast cancer cell proliferation through a lipid raft-mediated mechanism. Mol Pharmacol. 2006; 70(4):1298-1306.

49. Caffarel MM, Sarrio D, Palacios J, Guzman M and Sanchez C. Delta9-tetrahydrocannabinol inhibits cell cycle progression in human breast cancer cells through $\mathrm{Cdc} 2$ regulation. Cancer Res. 2006; 66(13):6615-6621.

50. Grimaldi C, Pisanti S, Laezza C, Malfitano AM, Santoro A, Vitale M, Caruso MG, Notarnicola M, Iacuzzo I, Portella G, Di Marzo V and Bifulco M. Anandamide inhibits adhesion and migration of breast cancer cells. Exp Cell Res. 2006; 312(4):363-373.

51. Ligresti A, Moriello AS, Starowicz K, Matias I, Pisanti S, De Petrocellis L, Laezza C, Portella G, Bifulco M and Di Marzo V. Antitumor activity of plant cannabinoids with emphasis on the effect of cannabidiol on human breast carcinoma. J Pharmacol Exp Ther. 2006; 318(3):1375-1387.

52. Di Marzo V, Melck D, Orlando $\mathrm{P}$, Bisogno $\mathrm{T}$, Zagoory O, Bifulco M, Vogel Z and De Petrocellis L. Palmitoylethanolamide inhibits the expression of fatty acid amide hydrolase and enhances the anti-proliferative effect of anandamide in human breast cancer cells. Biochem J. 2001; 358(Pt 1):249-255.

53. Ford LA, Roelofs AJ, Anavi-Goffer S, Mowat L, Simpson DG, Irving AJ, Rogers MJ, Rajnicek AM and Ross RA. A role for L-alpha-lysophosphatidylinositol and GPR55 in the modulation of migration, orientation and polarization of human breast cancer cells. Br J Pharmacol. 2010; 160(3):762-771.

54. Zlotnik A, Burkhardt AM and Homey B. Homeostatic chemokine receptors and organ-specific metastasis. Nat Rev Immunol. 2011; 11(9):597-606.

55. Ranger JJ, Levy DE, Shahalizadeh S, Hallett M and Muller WJ. Identification of a Stat3-dependent transcription regulatory network involved in metastatic progression. Cancer Res. 2009; 69(17):6823-6830.

56. De Petrocellis L, Melck D, Palmisano A, Bisogno T, Laezza $\mathrm{C}$, Bifulco M and Di Marzo V. The endogenous cannabinoid anandamide inhibits human breast cancer cell proliferation. Proc Natl Acad Sci U S A. 1998; 95(14):8375-8380.

57. Melck D, Rueda D, Galve-Roperh I, De Petrocellis L, Guzman M and Di Marzo V. Involvement of the cAMP/ protein kinase A pathway and of mitogen-activated protein kinase in the anti-proliferative effects of anandamide in human breast cancer cells. FEBS Lett. 1999; 463(3):235240.

58. von Bueren AO, Schlumpf $\mathrm{M}$ and Lichtensteiger W. Delta(9)-tetrahydrocannabinol inhibits 17beta-estradiolinduced proliferation and fails to activate androgen and estrogen receptors in MCF7 human breast cancer cells. Anticancer Res. 2008; 28(1A):85-89.

59. Caffarel MM, Moreno-Bueno G, Cerutti C, Palacios J, Guzman M, Mechta-Grigoriou F and Sanchez C. JunD is involved in the antiproliferative effect of Delta9tetrahydrocannabinol on human breast cancer cells. Oncogene. 2008; 27(37):5033-5044. 
60. Laezza C, Pisanti S, Crescenzi E and Bifulco M. Anandamide inhibits $\mathrm{Cdk} 2$ and activates Chk1 leading to cell cycle arrest in human breast cancer cells. FEBS Lett. 2006; 580(26):6076-6082.

61. Laezza C, d'Alessandro A, Malfitano AM and Bifulco M. Anandamide inhibits the Wnt/beta-catenin signalling pathway in human breast cancer MDA MB 231 cells. Eur J Cancer. 2013; 49(8):2066-2067.

62. Koller VJ, Zlabinger GJ, Auwarter V, Fuchs S and Knasmueller S. Toxicological profiles of selected synthetic cannabinoids showing high binding affinities to the cannabinoid receptor subtype CB(1). Arch Toxicol. 2013; 87(7):1287-1297.

63. Shrivastava A, Kuzontkoski PM, Groopman JE and Prasad A. Cannabidiol induces programmed cell death in breast cancer cells by coordinating the cross-talk between apoptosis and autophagy. Mol Cancer Ther. 2011; 10(7):1161-1172.

64. Chung SC, Hammarsten P, Josefsson A, Stattin P, Granfors T, Egevad L, Mancini G, Lutz B, Bergh A and Fowler CJ. A high cannabinoid $\mathrm{CB}(1)$ receptor immunoreactivity is associated with disease severity and outcome in prostate cancer. Eur J Cancer. 2009; 45(1):174-182.

65. Czifra G, Varga A, Nyeste K, Marincsak R, Toth BI, Kovacs I, Kovacs L and Biro T. Increased expressions of cannabinoid receptor-1 and transient receptor potential vanilloid-1 in human prostate carcinoma. J Cancer Res Clin Oncol. 2009; 135(4):507-514.

66. Ruiz L, Miguel A and Diaz-Laviada I. Delta9tetrahydrocannabinol induces apoptosis in human prostate PC-3 cells via a receptor-independent mechanism. FEBS Lett. 1999; 458(3):400-404.

67. Sanchez MG, Ruiz-Llorente L, Sanchez AM and DiazLaviada I. Activation of phosphoinositide 3-kinase/PKB pathway by $\mathrm{CB}(1)$ and $\mathrm{CB}(2)$ cannabinoid receptors expressed in prostate PC-3 cells. Involvement in Raf1 stimulation and NGF induction. Cell Signal. 2003; 15(9):851-859.

68. Nithipatikom K, Endsley MP, Isbell MA, Falck JR, Iwamoto Y, Hillard CJ and Campbell WB. 2-arachidonoylglycerol: a novel inhibitor of androgen-independent prostate cancer cell invasion. Cancer Res. 2004; 64(24):8826-8830.

69. Sarfaraz S, Afaq F, Adhami VM and Mukhtar H. Cannabinoid receptor as a novel target for the treatment of prostate cancer. Cancer Res. 2005; 65(5):1635-1641.

70. Brown I, Cascio MG, Wahle KW, Smoum R, Mechoulam R, Ross RA, Pertwee RG and Heys SD. Cannabinoid receptordependent and -independent anti-proliferative effects of omega-3 ethanolamides in androgen receptor-positive and -negative prostate cancer cell lines. Carcinogenesis. 2010; 31(9):1584-1591.

71. Guindon J and Hohmann AG. The endocannabinoid system and cancer: therapeutic implication. Br J Pharmacol. 2011; 163(7):1447-1463.
72. Pineiro R, Maffucci $T$ and Falasca M. The putative cannabinoid receptor GPR55 defines a novel autocrine loop in cancer cell proliferation. Oncogene. 2011; 30(2):142152.

73. Velasco L, Ruiz L, Sanchez MG and Diaz-Laviada I. delta(9)-Tetrahydrocannabinol increases nerve growth factor production by prostate PC-3 cells. Involvement of CB1 cannabinoid receptor and Raf-1. Eur J Biochem. 2001; 268(3):531-535.

74. Sarfaraz S, Afaq F, Adhami VM, Malik A and Mukhtar H. Cannabinoid receptor agonist-induced apoptosis of human prostate cancer cells LNCaP proceeds through sustained activation of ERK1/2 leading to G1 cell cycle arrest. J Biol Chem. 2006; 281(51):39480-39491.

75. Sanchez MG, Sanchez AM, Ruiz-Llorente L and DiazLaviada I. Enhancement of androgen receptor expression induced by (R)-methanandamide in prostate $\mathrm{LNCaP}$ cells. FEBS Lett. 2003; 555(3):561-566.

76. Olea-Herrero N, Vara D, Malagarie-Cazenave S and DiazLaviada I. Inhibition of human tumour prostate PC-3 cell growth by cannabinoids $\mathrm{R}(+)$-Methanandamide and JWH015: involvement of CB2. Br J Cancer. 2009; 101(6):940950.

77. Mimeault M, Pommery N, Wattez N, Bailly C and Henichart JP. Anti-proliferative and apoptotic effects of anandamide in human prostatic cancer cell lines: implication of epidermal growth factor receptor down-regulation and ceramide production. Prostate. 2003; 56(1):1-12.

78. Sreevalsan S, Joseph S, Jutooru I, Chadalapaka G and Safe $\mathrm{SH}$. Induction of apoptosis by cannabinoids in prostate and colon cancer cells is phosphatase dependent. Anticancer Res. 31(11):3799-3807.

79. Olea-Herrero N, Vara D, Malagarie-Cazenave S and Diaz-Laviada I. The cannabinoid $\mathrm{R}+$ methanandamide induces IL-6 secretion by prostate cancer PC3 cells. J Immunotoxicol. 2009; 6(4):249-256.

80. Cravatt BF, Giang DK, Mayfield SP, Boger DL, Lerner RA and Gilula NB. Molecular characterization of an enzyme that degrades neuromodulatory fatty-acid amides. Nature. 1996; 384(6604):83-87.

81. Cravatt BF, Demarest K, Patricelli MP, Bracey MH, Giang DK, Martin BR and Lichtman AH. Supersensitivity to anandamide and enhanced endogenous cannabinoid signaling in mice lacking fatty acid amide hydrolase. Proc Natl Acad Sci U S A. 2001; 98(16):9371-9376.

82. Ramer R, Heinemann K, Merkord J, Rohde H, Salamon A, Linnebacher M and Hinz B. COX-2 and PPAR-gamma confer cannabidiol-induced apoptosis of human lung cancer cells. Mol Cancer Ther. 2013; 12(1):69-82.

83. Vidinsky B, Gal P, Pilatova M, Vidova Z, Solar P, Varinska L, Ivanova L and Mojzis J. Anti-proliferative and antiangiogenic effects of CB2R agonist (JWH-133) in nonsmall lung cancer cells (A549) and human umbilical vein endothelial cells: an in vitro investigation. Folia Biol 
(Praha). 2012; 58(2):75-80.

84. Ravi J, Sneh A, Shilo K, Nasser MW and Ganju RK. FAAH inhibition enhances anandamide mediated anti-tumorigenic effects in non-small cell lung cancer by downregulating the EGF/EGFR pathway. Oncotarget. 2014; 5(9):2475-2486.

85. Blazquez C, Carracedo A, Barrado L, Real PJ, FernandezLuna JL, Velasco G, Malumbres M and Guzman M. Cannabinoid receptors as novel targets for the treatment of melanoma. Faseb J. 2006; 20(14):2633-2635.

86. Michalski CW, Oti FE, Erkan M, Sauliunaite D, Bergmann F, Pacher P, Batkai S, Muller MW, Giese NA, Friess H and Kleeff J. Cannabinoids in pancreatic cancer: correlation with survival and pain. Int J Cancer. 2008; 122(4):742-750.

87. Carracedo A, Gironella M, Lorente M, Garcia S, Guzman $\mathrm{M}$, Velasco $\mathrm{G}$ and Iovanna JL. Cannabinoids induce apoptosis of pancreatic tumor cells via endoplasmic reticulum stress-related genes. Cancer Res. 2006; 66(13):6748-6755.

88. Fogli S, Nieri P, Chicca A, Adinolfi B, Mariotti V, Iacopetti $\mathrm{P}$, Breschi $\mathrm{MC}$ and Pellegrini S. Cannabinoid derivatives induce cell death in pancreatic MIA PaCa-2 cells via a receptor-independent mechanism. FEBS Lett. 2006; 580(7):1733-1739.

89. Bovee JV, Hogendoorn PC, Wunder JS and Alman BA. Cartilage tumours and bone development: molecular pathology and possible therapeutic targets. Nat Rev Cancer. 2010; 10(7):481-488.

90. Bonneau A. Management of bone metastases. Can Fam Physician. 2008; 54(4):524-527.

91. Khasabova IA, Khasabov SG, Harding-Rose C, Coicou LG, Seybold BA, Lindberg AE, Steevens CD, Simone DA and Seybold VS. A decrease in anandamide signaling contributes to the maintenance of cutaneous mechanical hyperalgesia in a model of bone cancer pain. J Neurosci. 2008; 28(44):11141-11152.

92. Johnson JR, Burnell-Nugent M, Lossignol D, Ganae-Motan ED, Potts R and Fallon MT. Multicenter, double-blind, randomized, placebo-controlled, parallel-group study of the efficacy, safety, and tolerability of THC:CBD extract and THC extract in patients with intractable cancer-related pain. J Pain Symptom Manage. 2010; 39(2):167-179.

93. Hald A, Ding M, Egerod K, Hansen RR, Konradsen D, Jorgensen SG, Atalay B, Nasser A, Bjerrum OJ and Heegaard AM. Differential effects of repeated low dose treatment with the cannabinoid agonist WIN 55,212-2 in experimental models of bone cancer pain and neuropathic pain. Pharmacol Biochem Behav. 2008; 91(1):38-46.

94. Lozano-Ondoua AN, Wright C, Vardanyan A, King T, Largent-Milnes TM, Nelson M, Jimenez-Andrade JM, Mantyh PW and Vanderah TW. A cannabinoid 2 receptor agonist attenuates bone cancer-induced pain and bone loss. Life Sci. 2010; 86(17-18):646-653.

95. Potenzieri C, Harding-Rose C and Simone DA. The cannabinoid receptor agonist, WIN 55, 212-2, attenuates tumor-evoked hyperalgesia through peripheral mechanisms. Brain Res. 2008; 1215:69-75.

96. Hamamoto DT, Giridharagopalan S and Simone DA. Acute and chronic administration of the cannabinoid receptor agonist CP 55,940 attenuates tumor-evoked hyperalgesia. Eur J Pharmacol. 2007; 558(1-3):73-87.

97. Furuse S, Kawamata T, Yamamoto J, Niiyama Y, Omote $\mathrm{K}$, Watanabe $\mathrm{M}$ and Namiki A. Reduction of bone cancer pain by activation of spinal cannabinoid receptor 1 and its expression in the superficial dorsal horn of the spinal cord in a murine model of bone cancer pain. Anesthesiology. 2009; 111(1):173-186.

98. Curto-Reyes V, Llames S, Hidalgo A, Menendez L and Baamonde A. Spinal and peripheral analgesic effects of the CB2 cannabinoid receptor agonist AM1241 in two models of bone cancer-induced pain. Br J Pharmacol. 2010; 160(3):561-573.

99. Gu X, Mei F, Liu Y, Zhang R, Zhang J and Ma Z. Intrathecal administration of the cannabinoid 2 receptor agonist JWH015 can attenuate cancer pain and decrease mRNA expression of the 2B subunit of N-methyl-Daspartic acid. Anesth Analg. 2011; 113(2):405-411.

100. Lozano-Ondoua AN, Hanlon KE, Symons-Liguori AM, Largent-Milnes TM, Havelin JJ, Ferland HL, 3rd, Chandramouli A, Owusu-Ankomah M, Nikolich-Zugich T, Bloom AP, Jimenez-Andrade JM, King T, Porreca F, Nelson MA, Mantyh PW and Vanderah TW. Disease modification of breast cancer-induced bone remodeling by cannabinoid 2 receptor agonists. J Bone Miner Res. 2013; 28(1):92-107.

101. Blazquez C, Casanova ML, Planas A, Gomez Del Pulgar T, Villanueva C, Fernandez-Acenero MJ, Aragones J, Huffman JW, Jorcano JL and Guzman M. Inhibition of tumor angiogenesis by cannabinoids. Faseb J. 2003; 17(3):529-531.

102. Carracedo A, Lorente M, Egia A, Blazquez C, Garcia S, Giroux V, Malicet C, Villuendas R, Gironella M, GonzalezFeria L, Piris MA, Iovanna JL, Guzman M and Velasco G. The stress-regulated protein p8 mediates cannabinoidinduced apoptosis of tumor cells. Cancer Cell. 2006; 9(4):301-312.

103. Blazquez C, Salazar M, Carracedo A, Lorente M, Egia A, Gonzalez-Feria L, Haro A, Velasco G and Guzman M. Cannabinoids inhibit glioma cell invasion by downregulating matrix metalloproteinase-2 expression. Cancer Res. 2008; 68(6):1945-1952.

104. Ellert-Miklaszewska A, Kaminska B and Konarska L. Cannabinoids down-regulate PI3K/Akt and Erk signalling pathways and activate proapoptotic function of Bad protein. Cell Signal. 2005; 17(1):25-37.

105. Salazar M, Carracedo A, Salanueva IJ, Hernandez-Tiedra S, Lorente M, Egia A, Vazquez P, Blazquez C, Torres S, Garcia S, Nowak J, Fimia GM, Piacentini M, Cecconi F, Pandolfi PP, Gonzalez-Feria L, et al. Cannabinoid action induces autophagy-mediated cell death through stimulation 
of ER stress in human glioma cells. J Clin Invest. 2009; 119(5):1359-1372.

106. Nabissi M, Morelli MB, Santoni M and Santoni G. Triggering of the TRPV2 channel by cannabidiol sensitizes glioblastoma cells to cytotoxic chemotherapeutic agents. Carcinogenesis. 2013; 34(1):48-57.

107. Marcu JP, Christian RT, Lau D, Zielinski AJ, Horowitz MP, Lee J, Pakdel A, Allison J, Limbad C, Moore DH, Yount GL, Desprez PY and McAllister SD. Cannabidiol enhances the inhibitory effects of delta9-tetrahydrocannabinol on human glioblastoma cell proliferation and survival. Mol Cancer Ther. 2010; 9(1):180-189.

108. Torres S, Lorente M, Rodriguez-Fornes F, HernandezTiedra S, Salazar M, Garcia-Taboada E, Barcia J, Guzman $\mathrm{M}$ and Velasco G. A combined preclinical therapy of cannabinoids and temozolomide against glioma. Mol Cancer Ther. 2011; 10(1):90-103.

109. Gurley SN, Abidi AH, Allison P, Guan P, Duntsch C, Robertson JH, Kosanke SD, Keir ST, Bigner DD, Elberger $\mathrm{AJ}$ and Moore BM, 2nd. Mechanism of anti-glioma activity and in vivo efficacy of the cannabinoid ligand KM-233. J Neurooncol. 2012; 110(2):163-177.

110. Lorente M, Carracedo A, Torres S, Natali F, Egia A, Hernandez-Tiedra S, Salazar M, Blazquez C, Guzman M and Velasco G. Amphiregulin is a factor for resistance of glioma cells to cannabinoid-induced apoptosis. Glia. 2009; 57(13):1374-1385.

111. Lorente M, Torres S, Salazar M, Carracedo A, HernandezTiedra S, Rodriguez-Fornes F, Garcia-Taboada E, Melendez B, Mollejo M, Campos-Martin Y, Lakatosh SA, Barcia J, Guzman M and Velasco G. Stimulation of the midkine/ ALK axis renders glioma cells resistant to cannabinoid antitumoral action. Cell Death Differ. 2011; 18(6):959-973.

112. Lorente M, Torres S, Salazar M, Carracedo A, HernandezTiedra S, Rodriguez-Fornes F, Garcia-Taboada E, Melendez B, Mollejo M, Campos-Martin Y, Barcia JA, Guzman M and Velasco G. Stimulation of ALK by the growth factor midkine renders glioma cells resistant to autophagymediated cell death. Autophagy. 2011; 7(9):1071-1073.

113. Hernan Perez de la Ossa D, Lorente M, Gil-Alegre ME, Torres S, Garcia-Taboada E, Aberturas Mdel R, Molpeceres J, Velasco G and Torres-Suarez AI. Local delivery of cannabinoid-loaded microparticles inhibits tumor growth in a murine xenograft model of glioblastoma multiforme. PLoS One. 2013; 8(1):e54795.

114. Flygare J, Gustafsson K, Kimby E, Christensson B and Sander B. Cannabinoid receptor ligands mediate growth inhibition and cell death in mantle cell lymphoma. FEBS Lett. 2005; 579(30):6885-6889.

115. Wasik AM, Christensson B and Sander B. The role of cannabinoid receptors and the endocannabinoid system in mantle cell lymphoma and other non-Hodgkin lymphomas. Semin Cancer Biol. 2011; 21(5):313-321.

116. Liu WM, Scott KA, Shamash J, Joel S and Powles TB.
Enhancing the in vitro cytotoxic activity of Delta9tetrahydrocannabinol in leukemic cells through a combinatorial approach. Leuk Lymphoma. 2008; 49(9):1800-1809.

117. Gustafsson K, Sander B, Bielawski J, Hannun YA and Flygare J. Potentiation of cannabinoid-induced cytotoxicity in mantle cell lymphoma through modulation of ceramide metabolism. Mol Cancer Res. 2009; 7(7):1086-1098.

118. Gustafsson K, Christensson B, Sander B and Flygare J. Cannabinoid receptor-mediated apoptosis induced by $\mathrm{R}(+)$-methanandamide and Win55,212-2 is associated with ceramide accumulation and $\mathrm{p} 38$ activation in mantle cell lymphoma. Mol Pharmacol. 2006; 70(5):1612-1620.

119. Wasik AM, Almestrand S, Wang X, Hultenby K, Dackland AL, Andersson P, Kimby E, Christensson B and Sander B. WIN55,212-2 induces cytoplasmic vacuolation in apoptosis-resistant MCL cells. Cell Death Dis. 2011; 2:e225.

120. Lopes CF, de Angelis BB, Prudente HM, de Souza BV, Cardoso SV and de Azambuja Ribeiro RI. Concomitant consumption of marijuana, alcohol and tobacco in oral squamous cell carcinoma development and progression: recent advances and challenges. Arch Oral Biol. 2012; 57(8):1026-1033.

121. Liang C, McClean MD, Marsit C, Christensen B, Peters E, Nelson HH and Kelsey KT. A population-based casecontrol study of marijuana use and head and neck squamous cell carcinoma. Cancer Prev Res (Phila). 2009; 2(8):759768.

122. Shi Y, Zou M, Baitei EY, Alzahrani AS, Parhar RS, AlMakhalafi Z and Al-Mohanna FA. Cannabinoid 2 receptor induction by IL-12 and its potential as a therapeutic target for the treatment of anaplastic thyroid carcinoma. Cancer Gene Ther. 2008; 15(2):101-107.

123. Cozzolino R, Cali G, Bifulco $M$ and Laccetti P. A metabolically stable analogue of anandamide, Met-F-AEA, inhibits human thyroid carcinoma cell lines by activation of apoptosis. Invest New Drugs. 2010; 28(2):115-123.

124. Yamaguchi H, Wyckoff $\mathrm{J}$ and Condeelis J. Cell migration in tumors. Curr Opin Cell Biol. 2005; 17(5):559-564.

125. Cao Z, Shang B, Zhang G, Miele L, Sarkar FH, Wang Z and Zhou Q. Tumor cell-mediated neovascularization and lymphangiogenesis contrive tumor progression and cancer metastasis. Biochim Biophys Acta. 2013; 1836(2):273-286.

126. Laezza C, Pisanti S, Malfitano AM and Bifulco M. The anandamide analog, Met-F-AEA, controls human breast cancer cell migration via the RHOA/RHO kinase signaling pathway. Endocr Relat Cancer. 2008; 15(4):965-974.

127. Hall A. The cytoskeleton and cancer. Cancer Metastasis Rev. 2009; 28(1-2):5-14.

128. Thapa D, Lee JS, Heo SW, Lee YR, Kang KW, Kwak MK, Choi HG and Kim JA. Novel hexahydrocannabinol analogs as potential anti-cancer agents inhibit cell proliferation and tumor angiogenesis. Eur J Pharmacol. 2011; 650(1):64-71. 
129. Takeda S, Okajima S, Miyoshi H, Yoshida K, Okamoto Y, Okada T, Amamoto T, Watanabe K, Omiecinski CJ and Aramaki H. Cannabidiolic acid, a major cannabinoid in fiber-type cannabis, is an inhibitor of MDA-MB-231 breast cancer cell migration. Toxicol Lett. 2012; 214(3):314-319.

130. Nevalainen $\mathrm{T}$ and Irving AJ. GPR55, a lysophosphatidylinositol receptor with cannabinoid sensitivity? Curr Top Med Chem. 2010; 10(8):799-813.

131. Zhang H, Berezov A, Wang Q, Zhang G, Drebin J, Murali R and Greene MI. ErbB receptors: from oncogenes to targeted cancer therapies. J Clin Invest. 2007; 117(8):2051-2058.

132. Ursini-Siegel J, Schade B, Cardiff RD and Muller WJ. Insights from transgenic mouse models of ERBB2-induced breast cancer. Nat Rev Cancer. 2007; 7(5):389-397.

133. Massi P, Solinas M, Cinquina V and Parolaro D. Cannabidiol as potential anticancer drug. $\mathrm{Br} \mathrm{J}$ Clin Pharmacol. 2013; 75(2):303-312.

134. Ramer R and Hinz B. Inhibition of cancer cell invasion by cannabinoids via increased expression of tissue inhibitor of matrix metalloproteinases-1. J Natl Cancer Inst. 2008; 100(1):59-69.

135. Ramer R, Bublitz K, Freimuth N, Merkord J, Rohde H, Haustein M, Borchert P, Schmuhl E, Linnebacher M and Hinz B. Cannabidiol inhibits lung cancer cell invasion and metastasis via intercellular adhesion molecule-1. Faseb J. 2012; 26(4):1535-1548.

136. Massi P, Vaccani A, Bianchessi S, Costa B, Macchi P and Parolaro D. The non-psychoactive cannabidiol triggers caspase activation and oxidative stress in human glioma cells. Cell Mol Life Sci. 2006; 63(17):2057-2066.

137. Freimuth N, Ramer R and Hinz B. Antitumorigenic effects of cannabinoids beyond apoptosis. J Pharmacol Exp Ther. 2010; 332(2):336-344.

138. Soroceanu L, Murase R, Limbad C, Singer E, Allison J, Adrados I, Kawamura R, Pakdel A, Fukuyo Y, Nguyen D, Khan S, Arauz R, Yount GL, Moore DH, Desprez PY and McAllister SD. Id-1 is a key transcriptional regulator of glioblastoma aggressiveness and a novel therapeutic target. Cancer Res. 72013; 3(5):1559-1569.

139. Hoellen F, Kelling K, Dittmer C, Diedrich K, Friedrich M and Thill M. Impact of cyclooxygenase-2 in breast cancer. Anticancer Res. 2011; 31(12):4359-4367.

140. Farsandaj N, Ghahremani MH and Ostad SN. Role of cannabinoid and vanilloid receptors in invasion of human breast carcinoma cells. J Environ Pathol Toxicol Oncol. 2012; 31(4):377-387.

141. McAllister SD, Christian RT, Horowitz MP, Garcia A and Desprez PY. Cannabidiol as a novel inhibitor of Id-1 gene expression in aggressive breast cancer cells. Mol Cancer Ther. 2007; 6(11):2921-2927.

142. McAllister SD, Murase R, Christian RT, Lau D, Zielinski AJ, Allison J, Almanza C, Pakdel A, Lee J, Limbad C, Liu Y, Debs RJ, Moore DH and Desprez PY. Pathways mediating the effects of cannabidiol on the reduction of breast cancer cell proliferation, invasion, and metastasis. Breast Cancer Res Treat. 2011; 129(1):37-47.

143. Preet A, Qamri Z, Nasser MW, Prasad A, Shilo K, Zou X, Groopman JE and Ganju RK. Cannabinoid receptors, CB1 and CB2, as novel targets for inhibition of non-small cell lung cancer growth and metastasis. Cancer Prev Res (Phila). 2011; 4(1):65-75.

144. Guzman M. Cannabinoids: potential anticancer agents. Nat Rev Cancer. 2003; 3(10):745-755.

145. Preet A, Ganju RK and Groopman JE. Delta9Tetrahydrocannabinol inhibits epithelial growth factorinduced lung cancer cell migration in vitro as well as its growth and metastasis in vivo. Oncogene. 2008; 27(3):339346.

146. Takakura N. Formation and regulation of the cancer stem cell niche. Cancer Sci. 2012; 103(7):1177-1181.

147. Gustafsson SB, Wallenius A, Zackrisson H, Popova D, Plym Forshell L and Jacobsson SO. Effects of cannabinoids and related fatty acids upon the viability of P19 embryonal carcinoma cells. Arch Toxicol. 2013; 87(11):1939-1951.

148. Aguado T, Carracedo A, Julien B, Velasco G, Milman G, Mechoulam R, Alvarez L, Guzman M and Galve-Roperh I. Cannabinoids induce glioma stem-like cell differentiation and inhibit gliomagenesis. J Biol Chem. 2007; 282(9):68546862.

149. Wallace DC. Mitochondria and cancer. Nat Rev Cancer. 2012; 12(10):685-698.

150. Dando I, Donadelli M, Costanzo C, Dalla Pozza E, D'Alessandro A, Zolla L and Palmieri M. Cannabinoids inhibit energetic metabolism and induce AMPK-dependent autophagy in pancreatic cancer cells. Cell Death Dis. 2013; 4:e664.

151. Donadelli M, Dando I, Zaniboni T, Costanzo C, Dalla Pozza E, Scupoli MT, Scarpa A, Zappavigna S, Marra M, Abbruzzese A, Bifulco M, Caraglia M and Palmieri M. Gemcitabine/cannabinoid combination triggers autophagy in pancreatic cancer cells through a ROS-mediated mechanism. Cell Death Dis. 2011; 2:e152.

152. Whyte DA, Al-Hammadi S, Balhaj G, Brown OM, Penefsky HS and Souid AK. Cannabinoids inhibit cellular respiration of human oral cancer cells. Pharmacology. 2010; 85(6):328335.

153. Disis ML. Immune regulation of cancer. J Clin Oncol. 2010; 28(29):4531-4538.

154. Galve-Roperh I, Sanchez C, Cortes ML, Gomez del Pulgar $T$, Izquierdo $M$ and Guzman $M$. Anti-tumoral action of cannabinoids: involvement of sustained ceramide accumulation and extracellular signal-regulated kinase activation. Nat Med. 2000; 6(3):313-319.

155. Echigo R, Sugimoto N, Yachie A and Ohno-Shosaku T. Cannabinoids inhibit peptidoglycan-induced phosphorylation of NF-kappaB and cell growth in U87MG human malignant glioma cells. Oncol Rep. 2012; 28(4):1176-1180. 
156. Cencioni MT, Chiurchiu V, Catanzaro G, Borsellino G, Bernardi G, Battistini L and Maccarrone M. Anandamide suppresses proliferation and cytokine release from primary human T-lymphocytes mainly via CB2 receptors. PLoS One. 2010; 5(1):e8688.

157. Curran NM, Griffin BD, O’Toole D, Brady KJ, Fitzgerald $\mathrm{SN}$ and Moynagh PN. The synthetic cannabinoid R(+)WIN $55,212-2$ inhibits the interleukin-1 signaling pathway in human astrocytes in a cannabinoid receptor-independent manner. J Biol Chem. 2005; 280(43):35797-35806.

158. Yea SS, Yang KH and Kaminski NE. Role of nuclear factor of activated T-cells and activator protein-1 in the inhibition of interleukin-2 gene transcription by cannabinol in EL4 T-cells. J Pharmacol Exp Ther. 2000; 292(2):597-605.

159. Joseph J, Niggemann B, Zaenker KS and Entschladen F. Anandamide is an endogenous inhibitor for the migration of tumor cells and $\mathrm{T}$ lymphocytes. Cancer Immunol Immunother. 2004; 53(8):723-728.

160. Bifulco M, Laezza C, Pisanti S and Gazzerro P. Cannabinoids and cancer: pros and cons of an antitumour strategy. Br J Pharmacol. 2006; 148(2):123-135.

161. Vaughan CW and Christie MJ. Retrograde signalling by endocannabinoids. Handb Exp Pharmacol. 2005; (168):367383.

162. Badawy ZS, Chohan KR, Whyte DA, Penefsky HS, Brown $\mathrm{OM}$ and Souid AK. Cannabinoids inhibit the respiration of human sperm. Fertil Steril. 2009; 91(6):2471-2476.

163. Darmani NA, Janoyan JJ, Crim J and Ramirez J. Receptor mechanism and antiemetic activity of structurally-diverse cannabinoids against radiation-induced emesis in the least shrew. Eur J Pharmacol. 2007; 563(1-3):187-196.

164. Avraham Y, Ben-Shushan D, Breuer A, Zolotarev O, Okon A, Fink N, Katz V and Berry EM. Very low doses of delta 8-THC increase food consumption and alter neurotransmitter levels following weight loss. Pharmacol Biochem Behav. 2004; 77(4):675-684.

165. Feinshtein V, Erez O, Ben-Zvi Z, Eshkoli T, Sheizaf B, Sheiner E and Holcberg G. Cannabidiol enhances xenobiotic permeability through the human placental barrier by direct inhibition of breast cancer resistance protein: an ex vivo study. Am J Obstet Gynecol. 2013; 209(6):573.e1-e15.

166. Gomes FV, Del Bel EA and Guimaraes FS. Cannabidiol attenuates catalepsy induced by distinct pharmacological mechanisms via 5-HT receptor activation in mice. Prog Neuropsychopharmacol Biol Psychiatry. 2013; 46C:43-47.

167. Juknat A, Pietr M, Kozela E, Rimmerman N, Levy R, Gao F, Coppola G, Geschwind D and Vogel Z. Microarray and pathway analysis reveal distinct mechanisms underlying cannabinoid-mediated modulation of LPS-induced activation of BV-2 microglial cells. PLoS One. 2013; 8(4):e61462.

168. Karmaus PW, Wagner JG, Harkema JR, Kaminski NE and Kaplan BL. Cannabidiol (CBD) enhances lipopolysaccharide (LPS)-induced pulmonary inflammation in C57BL/6 mice. J Immunotoxicol. 2013; 10(3):321-328.

169. Deiana S. Medical use of cannabis. Cannabidiol: a new light for schizophrenia? Drug Test Anal. 2013; 5(1):46-51.

170. Granja AG, Carrillo-Salinas F, Pagani A, Gomez-Canas M, Negri R, Navarrete C, Mecha M, Mestre L, Fiebich BL, Cantarero I, Calzado MA, Bellido ML, Fernandez-Ruiz J, Appendino G, Guaza C and Munoz E. A cannabigerol quinone alleviates neuroinflammation in a chronic model of multiple sclerosis. J Neuroimmune Pharmacol. 2012; 7(4):1002-1016.

171. Borrelli F, Fasolino I, Romano B, Capasso R, Maiello F, Coppola D, Orlando P, Battista G, Pagano E, Di Marzo V and Izzo AA. Beneficial effect of the non-psychotropic plant cannabinoid cannabigerol on experimental inflammatory bowel disease. Biochem Pharmacol. 2013; 85(9):13061316.

172. Hill AJ, Williams CM, Whalley BJ and Stephens GJ. Phytocannabinoids as novel therapeutic agents in CNS disorders. Pharmacol Ther. 2012; 133(1):79-97.

173. Izzo AA, Capasso R, Aviello G, Borrelli F, Romano B, Piscitelli F, Gallo L, Capasso F, Orlando P and Di Marzo V. Inhibitory effect of cannabichromene, a major nonpsychotropic cannabinoid extracted from Cannabis sativa, on inflammation-induced hypermotility in mice. $\mathrm{Br} \mathrm{J}$ Pharmacol. 2012; 166(4):1444-1460.

174. Shinjyo N and Di Marzo V. The effect cannabichromene on adult neural stem/progenitor cells. Neurochem Int. 2013; 63(5):432-7.

175. DeLong GT, Wolf CE, Poklis A and Lichtman AH. Pharmacological evaluation of the natural constituent of Cannabis sativa, cannabichromene and its modulation by Delta(9)-tetrahydrocannabinol. Drug Alcohol Depend. 2010; 112(1-2):126-133.

176. Batkai S, Mukhopadhyay P, Horvath B, Rajesh M, Gao RY, Mahadevan A, Amere M, Battista N, Lichtman AH, Gauson LA, Maccarrone M, Pertwee RG and Pacher P. Delta8-Tetrahydrocannabivarin prevents hepatic ischaemia/reperfusion injury by decreasing oxidative stress and inflammatory responses through cannabinoid CB2 receptors. Br J Pharmacol. 2012; 165(8):2450-2461.

177. Bolognini D, Costa B, Maione S, Comelli F, Marini P, Di Marzo V, Parolaro D, Ross RA, Gauson LA, Cascio MG and Pertwee RG. The plant cannabinoid Delta9tetrahydrocannabivarin can decrease signs of inflammation and inflammatory pain in mice. Br J Pharmacol. 2010; 160(3):677-687.

178. De Petrocellis L, Orlando P, Moriello AS, Aviello G, Stott C, Izzo AA and Di Marzo V. Cannabinoid actions at TRPV channels: effects on TRPV3 and TRPV4 and their potential relevance to gastrointestinal inflammation. Acta Physiol (Oxf). 2012; 204(2):255-266.

179. Liu YJ, Fan HB, Jin Y, Ren CG, Jia XE, Wang L, Chen Y, Dong M, Zhu KY, Dong ZW, Ye BX, Zhong Z, Deng M, Liu TX and Ren R. Cannabinoid receptor 2 suppresses 
leukocyte inflammatory migration by modulating the JNK/ c-Jun/Alox5 pathway. J Biol Chem. 2013; 288(19):1355113562.

180. Aso E, Juves S, Maldonado R and Ferrer I. CB2 cannabinoid receptor agonist ameliorates Alzheimer-like phenotype in AbetaPP/PS1 mice. J Alzheimers Dis. 2013; 35(4):847-858.

181. Merroun I, Sanchez-Gonzalez C, Martinez R, Lopez-Chaves C, Porres JM, Aranda P, Llopis J, Galisteo M, Zarzuelo A, Errami M and Lopez-Jurado M. Novel effects of the cannabinoid inverse agonist AM 251 on parameters related to metabolic syndrome in obese Zucker rats. Metabolism. 2013; 62(11):1641-50.

182. Vaseghi G, Rabbani $M$ and Hajhashemi V. The CB(1) receptor antagonist, AM281, improves recognition loss induced by naloxone in morphine withdrawal mice. Basic Clin Pharmacol Toxicol. 2012; 111(3):161-165.

183. Rabbani M, Vaseghi $G$ and Hajhashemi V. AM281, Cannabinoid Antagonist/Inverse agonist, Ameliorates Scopolamine-Induced Cognitive Deficit. Iran J Basic Med Sci. 2012; 15(5):1106-1110. 